\title{
招待論文 \\ 地盤への油の浸透に関する基礎的研究 \\ BASIC EXPERIMENTAL RESEARCH ON OIL CONTAMINATION OF SUBSURFACE MATERIAL
}

\author{
西垣 誠 1 ・菅野雄一 2 \\ Makoto NISHIGAKI and Yuichi KANNO \\ 1 正会員 岡山大学大学院教授 環境学研究科（T700-8530 岡山市津島中 3-1-1） \\ E-mail: n_makoto@cc.okayama-u.ac.jp \\ 2 正会員＼cjkstart復建調査設計株式会社＼cjkstart地盤環境部（干720-0052 広島市東区光町 2-10-11） \\ E-mail: y-kanno@fukken.co.jp
}

Key Words : oil contamination, unsaturated flow, effective porosity, mass transport

\begin{abstract}
本研究は土袞・地下水污染の中で現在問題となっている油污染の定量的な取り扱いについて論述する. すな わち, 水, 空気, 油の三相流体の多孔質内の流動を支配する浸透特性を室内試験によってどのように求めるか を検討した. 試験法としては, $\gamma$ 線による瞬時水分計測法と比較的簡単な Green-Ampt モデル試験法とを比較 して, Green-Ampt の簡単な試験法の適用性について吟味した.
\end{abstract}

\section{1. はじめに}

土壌・地下水污染の現状に関しては環境省等の行政 機関によって，我が国の統計的なデータが収録されて おり ${ }^{1)}$, 今日では多くの人々が污染の現状がわかるよ うになっている. また, 平田ら执よび著者によっても 土壤・地下水污染問題と対策の最近の動向がまとめら れている ${ }^{2) ~}{ }^{5}$.

このような我が国の土袞・地下水污染の現状に対し て, 我が国の周辺の国々（バングラディシュ，ネパー ル, 内蒙古, ベトナム) では, 砒素污染による人体へ の影響が出ているように重大な課題になっている ${ }^{6,7)}$. 現在では, 日本の食料の 6 割近くが海外からの輸入に よって満たされているとなると, 海外の土袞・地下水 污染の影響は, 直接我々の食の安全に影響すると考え ると地球規模でのこの分野の対策あるいは浄化を検討 する必要が出てくる.

土壤・地下水污染の中の揮発性有機塩素化合物によ る地下水污染の大規模な污染の状況もほぼわかってき ている.たとえば近畿の水瓶である琵琶湖の左岸地区 の地下水の多くが四塩化炭素やトリクロロエチレン等 によって污染されている現状も明確になっている ${ }^{8)}$. このような揮発性有機塩素化合物による土㙵・地下水 污染に対しては種々の新しい修復手法も提案され, そ の手法が実際のフィールドに適用されている ${ }^{9)}$.

これらの土㙵・地下水污染について, 新しく油污染 に対して 2006 年 3 月に環境省から「油污染対策ガイド ライン」が発表された。このガイドラインは調査の基 本的な考え方と対策を選択する際の考え方を示したも
のであり，技術的な検討領域を多く含んでいる.

したがって, 本研究では, 種々の土壌・地下水污染の 中で油による土畩・地下水污染を定量的に評価するた めにその浸透特性をどのように実験的に求めるかにつ いて論述する. すなわち, 一般に油の污染機構を解明 し，その挙動を予測するためには，三相系の浸透特性 である毛管上昇高一飽和度一相対透過係数の関係（以 後 PSKR と記す）をモデル化する必要がある.

本研究では, このような複雑な三相系の浸透特性を RI （ $\gamma$ 線）を用いた瞬時水分計測法により計測する方法を 示す．また，このような高度かつ複雑な試験装置を用い ない簡単な一次元の浸透試験装置によってもPSKRを 求める可能性を模索し，その適用性について論議する.

\section{2. 油による土壤・地下水污染}

油による地盤污染の拡散過程について, 図-1の例で 考えてみる. 油による地盤污染の多くは, タンクから 漏洩した油が不飽和地盤を通過することによって生じ ると考えられる。一般に，不飽和地盤では水と空気が 存在し，二相系の流れが構成される. そして，そこに 油が浸透することによって, 不飽和地盤は油・水・空 気の三相系の流れが構成される. また, 油が地下水面 に達するまでは, 重力の作用により鉛直方向の浸透が 卓越している状態にある. その後, 油の浸潤面の一部 は地下水面と接し, それ以降は油が不飽和土中を浸潤 していく現象と地下水面下の飽和土中の水を押し出し て浸透していく現象が同時に進行する. 地下水面に達 した油は地下水の流れに応じて，下流側へと流出する 


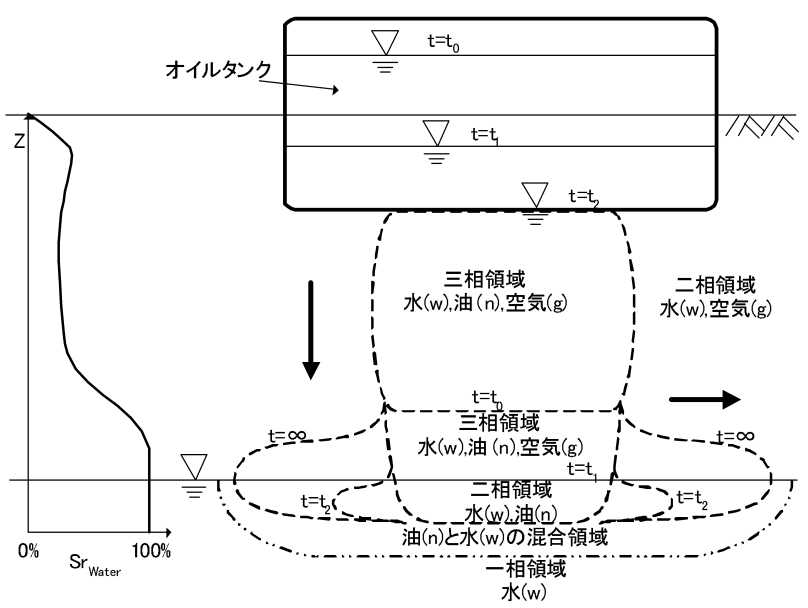

図-1 油の地盤内への浸透における多相系

とともに，一部は地下水への溶解や揮発性成分がガス 化して間隙空気に広がる．地下水の流れがある場合に は，地下水の流れに合わせて油の流れは水平方向に卓 越し, 空気, 水, 油の三相系の流れが構成される。 た, 地下水面下の飽和地盤内の水を押し出して浸透す る範囲では, 水と油の二相系の流れが構成される.

このような油の浸透過程を考えると, 油による污染 は三相系による非混合流体の不飽和浸透理論で表現さ れ, 連続の方程式とダルシーの法則より, 導き出され る.このような，不飽和浸透流を考える上で重要なパ ラメータは, PSKRである. ここで, 相対透過係数は, 水を流体とする場合には, 飽和透水係数とある飽和度 の透水係数の比を示す. 透過係数は水の場合には透水 係数, 油の場合には透油係数である.

湿潤性の異なる 2 つ流体が多孔質媒体に存在する 時, 湿潤流体は優先的に狭い間隙の中に引き込まれ, 非 湿潤流体は大きな間隙にとどまる性質がある，湿潤流 体（液体）と非湿潤流体（気体）の境界面での圧力差 が毛管圧力である. 毛管圧力は多孔質媒体に引き込ま れる湿潤性流体の飽和度と関連がある.この毛管圧力 と飽和度の関係は多孔質媒体に対する特徴的なマクロ スケール関係を導き出す。

Leverett は二相系流れでは, 毛管圧力を無次元化する ことで, 流体の組み合わせに関係なく, 湿潤流体の飽 和度の関数 ( $\mathrm{J}$ 関数) で表されることを 50 数年前に実 験的に示した ${ }^{10)}$. 水一空気の二相系流れにおける有名 な J 関数は Brooks and Corey ${ }^{11)}$, Van Genuchten ${ }^{12)}$ によ る関数である. 毛管上昇高 $h_{c}$ は毛管圧力 $P_{c}\left(=\rho_{w} g h_{c}\right)$ を水柱の高さで表した值である．ここで， $\rho_{w}$ は水の密 度, $g$ は重力である.

三相系での毛管上昇高と飽和度の関係について, Parker

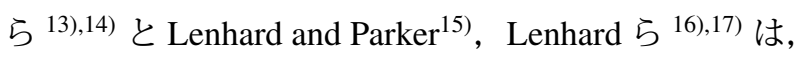
三相系での実験により，2つの二相系の毛管上昇高と 飽和度の関係より，三相系での毛管上昇高と飽和度の
関係を記述する手法の有効性を示した．水一油一空気 の三相系においては, 湿潤性の高い順番に間隙を埋め, 間隙内部での境界面は水一油間, 油一空気間でのみ存 在すると仮定している.

二相系での相対透過係数と飽和度の関係について, Burdine $^{18)}$, Mualem ${ }^{19)}$ は毛管モデルを適用して, 飽和 度と毛管上昇高による積分式を提案した. 一般的に, こ れらの積分式に Brooks and Corey ${ }^{11)}$ と Van Genuchten ${ }^{12)}$ が示した毛管上昇高と飽和度関係を導入し, 解析的に 積分することにより, 定式化して, 相対透過係数を飽 和度の関数として用いられる.

三相系での飽和度と相対透過係数の関係については, 三相系で相対透過係数と飽和度関係を測定せずに決定 する手法として，1970，1973 年の Stone ${ }^{20), 21)}$ による 2 つの手法と 1987 年の Parker ら ${ }^{13), 14)}$ による手法が示さ れた. これらの方法では, 三相系での油の相対透過係 数と飽和度の関係は水と油, 油と空気の二相系から決 定されるとしている. また, 水の相対透過係数は, 水 の飽和度のみに依存し, 油と空気の相対透過係数は三 相すべての飽和度に依存することを示した。

Van Geel は 2 次元の実験結果と解析結果の比較より, 地下の不飽和帯を浸透する過程で, 不飽和帯に保持され る残留油の影響が考慮されない解析は, 現実よりも不飽 和帯に保持される油の量は少なく見積もり, 油が水面に 到達した後の水平移動範囲を広く見積もる可能性があ ることを指摘した ${ }^{22), 23)}$. この残留油の推定方法に関し ては, Van Geel and Roy ${ }^{24)}$, Wipfler and Van Der Zee ${ }^{25)}$, Lenhard ら 26)によって提案されている. Oostorm ら 27) は, 新たにこれらの関係式を提案し, その有効性を彼 らの提案式を実験および解析と比較検討している.

また，国内では，藤縄・高橋は乾燥および水湿潤状 態で 3 種類の石油 (ガソリン, 灯油, 軽油) および水と エタノールの毛管上昇実験を行い, 水が残留した状態 では, 乾燥状態に対して石油の移動性が低下すること を明らかにした ${ }^{28)}$. 更に藤縄・高橋は, 非平衡毛管上 昇に対する Washburn 方程式から導いた解析解が別途, Green and Ampt（以降，このモデルを GAM とする.） の浸潤方程式より導いた解析解と符合することを示し, 各流体の流動係数, 平衡毛管上昇高, 接触角, 等価管 半径を計算した結果を示した.

棚橋・佐藤は, 灯油で飽和された土試料に対して, 通 水することによる排油過程で残る残留油飽和度および 水で飽和された土試料に対して通油することによる浸 入油飽和度に関する実験を行った ${ }^{29)}$. その結果, 棚橋・ 佐藤は, 残留油飽和度が平均断面流速と水分保持特性 曲線に対するVan Genuchten の提案した変数 $\alpha, n$ の関 数で近似されることと, 浸入油飽和度が平均断面流速 と残留水飽和度の関数で近似されることを示した. 
登坂らは, 多成分多相型拡散モデルの数值解析プロ グラムを開発し, 実務に適用している ${ }^{30)}$ 。また, 多田 らは, 相対透過係数と飽和度との関係に着目して, その 設定方法の差異が油の挙動に与える影響について, 数 值計算を行った結果を示している ${ }^{31) .}$

Hinkelmann ${ }^{32)}$ は, Helmig ${ }^{33)} の$ 多相流の解析手法を 地表水との関係も導入したソフト（MUFTE-UG）を開 発し，その並列型のコンピューターによる取り扱いや 自動要素分解による解説を行っている.

\section{3. 二相系および三相系の不飽和浸透理論}

\section{（1）多相流の支配方程式}

多孔質媒体での多相流のモデル化は，各相，多相・ 多成分流モデルについては各成分に対して連続方程式 を誘導し, 運動方程式は一般化された Darcy 則で記述 すると, 不飽和多相系の支配方程式は仮に Helmig の著 書に従うと次式で示される ${ }^{33)}$.

$$
\frac{\partial\left(S_{\alpha} \phi \rho_{\alpha}\right)}{\partial t}-\nabla \cdot\left\{\rho_{\alpha} \frac{k_{r \alpha}}{\mu_{\alpha}} K\left(\nabla p_{\alpha}-\rho_{\alpha} g\right)\right\}-r_{\alpha}=0
$$

また，各流体の毛管上昇高と飽和度の関係が支配方 程式の拘束条件となる.

$$
\begin{gathered}
\sum_{\alpha=1}^{\text {nphas }} S_{\alpha}=1 \\
p_{c \varphi \alpha}=p_{\varphi}-p_{\alpha}=f\left(S_{1}, \ldots, S_{\text {nphas }}\right) \\
\forall \alpha, \varphi, \alpha \neq \varphi
\end{gathered}
$$

ここで, $S_{\alpha}$ : 相 $\alpha$ の飽和度, $\phi$ : 間隙率, $\rho_{\alpha}$ : 相 $\alpha$ の密 度, $k_{r \alpha}:$ 相 $\alpha$ の相対透過係数, $K$ : 物理的透過 係数, $\mu_{\alpha}$ : 相 $\alpha$ の粘性係数, $p_{\alpha}$ : 相 $\alpha$ の圧力, $g$ : 重力加速度, $p_{c \phi \alpha}:$ 相 $\phi$ と相 $\alpha$ 間の毛管圧 力, $r_{\alpha}$ : 体積フラックス, nphase: 相の数.

式 (2) では, 油, 空気, 水のそれぞれで毛管上昇高, 飽和度, 相対透過係数の 9 つの未知数を有する. この うち, 飽和度は毛管上昇高との関数として与えられ, 相 対透過係数は飽和度との関数として与えられる. した がって, 支配方程式の定式化では, 飽和度と毛管上昇 高を変数として, 圧力定式化, 圧力-飽和度定式化, 飽 和度定式化の 3 つの定式化方法がある. 支配方程式の 定式化および数值解析手法については, 藤縄 ${ }^{34)}$, 藤縄・ 日比 ${ }^{35), 36), 37)}$, Helmig の著書 ${ }^{38)} て ゙$ 詳細に紹介されてい るので，ここでは割愛するが，この方程式から実際に 油の挙動を定量的に計測するには表-1に示すパラメー タが必要である.

\section{（2）二相系流れでの毛管上昇高と飽和度の関係}

二相系流れ (水と空気系, 図-1 での二相領域) での毛
表-1 多相流解析に必要となるパラメータ

\begin{tabular}{l|l}
\hline 各相の密度 & $\rho_{\alpha}$ \\
各相の粘性係数 & $\mu_{\alpha}$ \\
物理的透過係数 & $K$ \\
間隙率 & $\phi$ \\
各相の相対透過係数 飽和度 & $k_{r \alpha} \sim S_{\alpha}$ \\
各相の毛管上昇高〜 飽和度 & $P_{c \phi \alpha} \sim S_{\alpha}$ \\
残留湿潤相飽和度 & $S_{w r}$ \\
残留非湿潤相飽和度 & $S_{n r}$ \\
\hline
\end{tabular}

管上昇高と飽和度の関係は, 一般的に, Van Genuchten ${ }^{12)}$ や Brooks and Corey ${ }^{11}$ 等による水と空気の二相系を対 象とした経験的な数学関数で決定される. 水等の液体 と空気の二相系の場合には, 両者の飽和度には次式の 関係が成り立つ。

$$
S_{w}+S_{a}=1
$$

ここで, $S_{w}$ : 水の飽和度, $S_{a}$ : 空気の飽和度.

また, 排水過程によって, 大部分の液体が流出した 後も, 土粒子に吸着し, 土粒子から離れない液体が存 在する.このような吸着し, 不動な液体の存在は, 液 体の流れに影響する有効間隙率を小さくする．このよ うな液体の飽和度を残留飽和度 $S_{w r}$ と定義し, 液体の 流れに寄与する液体の有効飽和度 $\underline{S}_{w}$ との間には次式 の関係が成り立つ.

$$
\underline{S}_{w}=\frac{S_{w}-S_{w r}}{1-S_{w r}}
$$

ここで, $\underline{S}_{w}$ : 水の有効飽和度, $S_{w}$ : 水の飽和度, $S_{w r}$ : 水の残留飽和度.

Van Genuchten による液体と空気の二相系での毛管 上昇高と飽和度の経験式は, 次式で表される ${ }^{3)}$.

$$
\underline{S}_{w}=\left[1+\left(\alpha h_{c}\right)^{n}\right]^{-m}
$$

ここで, $\alpha, n$ :フィッティングパラメータ, $m=1-1 / n$, $h_{c}:$ 空気と水の間に生じる毛管上昇高.

一般に， $\alpha$ は液体で飽和した多孔質媒体への空気の 浸入圧力の逆数, $n$ は流体の特性に関係なく, 多孔質 媒体の均質性を表す土壌に固有の形状パラメータであ る.これらのパラメータの求め方についてはすでに $\mathrm{pF}$ 試験として研究され, 実務で用いられている.

\section{（3）三相系流れでの毛管上昇高と飽和度の関係}

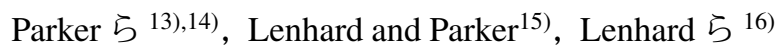
は三相系のモデルでは, 固体等の土袞への湿潤性は水, 油, 空気の順番で小さくなり, 図-2 に示すように湿潤性 の順番に応じて, 小さな間隙を満たすと仮定する ${ }^{15), 16) .}$ この仮定に基づくと, 間隙内部では, 油一水境界, 空 気一油境界の 2 つ境界が存在する. したがって, 三 相系における毛管上昇高と飽和度の関係は, 油一水お 


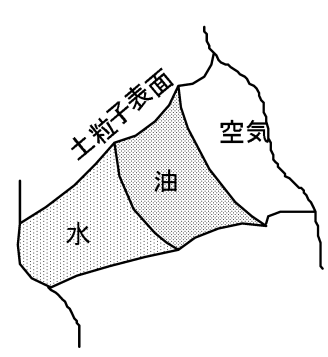

図-2 理想化された間隙での三相系

よび空気一油の 2 つの毛管上昇高と飽和度の組み合わ せによって記述する方法の有効性を示している。

Van Genuchten の毛管上昇高と飽和度の関係（以下， VG モデルと呼ぶ.）に基づき，水の有効飽和度と液体 有効飽和度で定式化された毛管上昇高の関係は式(6)で 表すことができる.

$$
\underline{S}_{w}=\left[1+\left(\alpha h_{c n w}\right)^{n}\right]^{-m}, \quad \underline{S}_{t}=\left[1+\left(\alpha h_{c a n}\right)^{n}\right]^{-m}
$$

Parker and Lenhard は，二相系と三相系における有効 飽和度を式 (7) のように定義した ${ }^{13), 14) .}$

$$
\begin{gathered}
\underline{S}_{w}=\frac{S_{w}-S_{w r}}{1-S_{w r}}, \quad \underline{S}_{n}=\frac{S_{n}}{1-S_{w r}} \\
\underline{S}_{a}=\frac{S_{a}}{1-S_{w r}} \\
\underline{S}_{t}=\frac{S_{w}+S_{n}-S_{w r}}{1-S_{w r}}=\underline{S}_{w}+\underline{S}_{n}=1-\underline{S}_{n}
\end{gathered}
$$

ここで, $\underline{S}_{w}$ : 水の有効飽和度, $\underline{S}_{t}$ : 液体の有効飽和度, $\underline{S}_{a}:$ 空気の有効飽和度, $\underline{S}_{n}:$ 油の有効飽和度, $h_{c n w}$ : 水一油間の毛管上昇高, $h_{c a n}$ : 油一空気 間の毛管上昇高.

湿潤性の低い油と空気の有効飽和度は, 封じ込めら れた流体や自由な流体の飽和度により, 次式のように 定義される.

$$
\begin{gathered}
\underline{S}_{n}=\underline{S}_{n f}+\underline{S}_{n t}, \quad \underline{S}_{a}=\underline{S}_{a f}+\underline{S}_{a t} \\
\underline{S}_{a t}=\underline{S}_{a t w}+\underline{S}_{a t n}
\end{gathered}
$$

ここで,

$\underline{S}_{n f}$ : 自由に移動できる油の有効飽和度,

$\underline{S}_{n t}:$ 封じ込められた油の有効飽和度,

$\underline{S}_{a f}:$ 自由に移動できる空気の有効飽和度,

$\underline{S}_{a t}:$ 封じ込められた空気の有効飽和度,

$\underline{S}_{a t w}$ : 水の中に封じ込められた空気の有効飽和度,

$\underline{S}_{a t n}:$ 油に封じ込められた空気の有効飽和度.

また, Parker and Lenhard は, 湿潤性流体の中に非湿 潤性流体が封じ込められる効果を定量化するため，見 かけ飽和度を式 (9)にて定義した ${ }^{13), 14) .}$

$$
\underline{S}_{w}=\underline{S}_{w}+\underline{S}_{n t}+\underline{S}_{a t w}, \quad \underline{S}_{t}=\underline{S}_{w}+\underline{S}_{n}+\underline{S}_{a t}
$$

ここで, $\underline{\underline{S}}_{w}$ : 見かけ水飽和度, $\underline{\underline{S}}_{t}$ : 見かけ液体飽和度.
これに加えて, 排水過程と湿潤過程によって生じる ヒステリシスを考慮するため，パラメータ $\alpha$ を排水過 程と湿潤過程それぞれで設定することで次式で説明で きる.

$$
{ }^{i} \underline{\underline{S}}=\left[1+\left(\alpha_{i} h_{c}\right)^{n}\right]^{-m}, \quad \underline{\underline{d}}=\left[1+\left(\alpha_{d} h_{c}\right)^{n}\right]^{-m}
$$

ここで, ${ }^{d} \underline{S}:$ 排水過程での見かけ飽和度,

${ }^{i} \overline{\bar{S}}$ : 湿潤過程での見かけ飽和度.

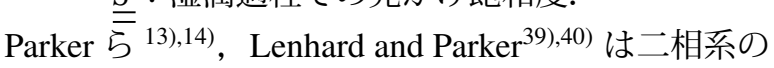
毛管上昇高と飽和度の関数は, スケール係数 $\beta$ を使用 することを提案した.

$$
\begin{aligned}
\underline{S}_{a w}\left(\beta_{a w} h_{c a w}\right) & =\underline{S}_{w}^{a w}\left(\beta_{n w} h_{c n w}\right)=\underline{S}_{n}^{a n}\left(\beta_{a n} h_{c a n}\right) \\
& =\left\{1+\left(\alpha h_{c}^{*}\right)^{n}\right\}^{-m}
\end{aligned}
$$

ここで, $\beta_{i j}: a, n, w$ 二相系でのスケール係数, $h_{c}^{*}$ : スケール化された毛管上昇高.

また，スケール係数 $\beta$ は表面張力や界面張力の比で 表すことができる.

$$
\begin{gathered}
\beta_{a w}=\sigma_{a w} / \sigma_{a w}=1.0, \quad \beta_{n w}=\sigma_{a w} / \sigma_{n w} \\
\beta_{a n}=\sigma_{a w} / \sigma_{a n}
\end{gathered}
$$

ここで, $\sigma_{a w}$ : 空気と水の表面張力, $\sigma_{a n}$ : 油と空気の 表面張力, $\sigma_{n w}$ : 油と水の界面張力.

三相系での毛管圧力一飽和度関係は，水一油および 油一空気の 2 つの二相系の毛管上昇高と見かけ飽和度 の関係より，次式のように定義した（以下，LP モデル と呼ぶ)。

$$
\begin{aligned}
{ }^{i, d} \underline{\underline{S}}_{w} & =\left[1+\left(\alpha_{i, d} \beta_{n w} h_{c n w}\right)^{n}\right]^{-m} \\
{ }^{i, d} \underline{\underline{S}}_{t} & =\left[1+\left(\alpha_{i, d} \beta_{a n} h_{c a n}\right)^{n}\right]^{-m}
\end{aligned}
$$

毛管上昇高が二相間の圧力の差であると定義される なら，三相系において式(14)の平衡式が成り立つ. そ して，スケール係数 $\beta$ には式 (15) の関係が成り立つ.

$$
\begin{gathered}
h_{c n w}+h_{c a n}=h_{c a w} \\
\frac{1}{\beta_{n w}}+\frac{1}{\beta_{a n}}=\frac{1}{\beta_{a w}}
\end{gathered}
$$

また，上式は表面張力によって次のように表すこと ができる.

$$
\sigma_{n w}+\sigma_{a n}=\sigma_{a w}
$$

水一空気表面での油の拡がりを表す伸展係数 (Spreading coefficient) は式(17)のように定義される ${ }^{38)}$. 式(16) が成り立つのは, $C_{s p}=0$ が満たされる場合である. 結 果的には, 三相系の平衡モデルでの毛管上昇高のスケー リングはこの制約のもとに妥当なものである.

$$
C_{s p}=\sigma_{a w}-\left(\sigma_{a n}+\sigma_{n w}\right)
$$




\section{（4）二相系での相対透過係数と飽和度の関係}

水, 空気の二相系の相対透過係数は, Mualem ${ }^{19)}$ が提 案する毛管モデルと Van Genuchten の飽和度と毛管上 昇高の関係より, 次式が示される（以下, VGM モデル と呼ぶ).

$$
\begin{aligned}
& k_{r w}=\underline{S}_{w}^{\zeta}\left[1-\left(1-\underline{S}_{w}^{1 / m}\right)^{m}\right]^{2} \\
& k_{r a}=\left(1-\underline{S}_{w}\right)^{\gamma}\left(1-\underline{S}_{w}^{1 / m}\right)^{2 m}
\end{aligned}
$$

ここで， $\zeta, \gamma$ は間隙の連続性に関わるパラメータであ る. 一般には， $\zeta=1 / 2, \gamma=1 / 3$ が用いられる.

\section{（5）三相系での相対透過係数と飽和度の関係}

水, 空気, 油の三相系での相対透過係数は水の有効 飽和度と液体の有効飽和度の関数として, 次式 (19a) (19c) で示される 13),14)（以下，LPモデルと呼ぶ). 式 (19c) では，水相に封じ込められた油の影響が考慮さ れていないため, Helmig は式(19d) を提案している ${ }^{38)}$ (He モデルと呼ぶ).

$$
\begin{gathered}
k_{r w}=\underline{S}_{w}^{1 / 2}\left[1-\left(1-\underline{S}_{w}^{1 / m}\right)^{m}\right]^{2} \\
k_{r a}=\left(1-\underline{S}_{t}\right)^{1 / 2}\left(1-\underline{S}_{t}^{1 / m}\right)^{2 m} \\
k_{r n}=\left(\underline{S}_{t}-\underline{S}_{w}\right)^{1 / 2}\left[\left(1-\underline{S}_{w}^{1 / m}\right)^{m}-\left(1-\underline{S}_{t}^{1 / m}\right)^{m}\right]^{2} \\
k_{r n}=\left(\frac{S_{n}-S_{n r}}{1-S_{w r}}\right)^{1 / 2}\left[\left(1-\underline{S}_{w}^{1 / m}\right)^{m}-\left(1-\underline{S}_{t}^{1 / m}\right)^{m}\right]^{2}
\end{gathered}
$$

\section{4. 実験に用いた砂試料および油の特性}

\section{（1）使用した油の物性}

本研究では, 油として石油タンクの油に近いものを試 験に用いた．その物性を表-2に示す．油の比重と粘性 は温度により変化するため, 図-3に油の粘性係数と温 度の関係，図-4に油の比重と温度の関係を示す．図-3 および図-4 より温度の上昇とともに粘性係数および単 位体積重量が減少することがわかる.

\section{（2）使用した砂試料の物性}

実験には豊浦標準砂を用いた。図-5に砂の粒度分布

\section{表-2 実験に用いた油の物性值}

\begin{tabular}{l|l}
\hline 名称 & 電気絶縁油 \\
規格 & JIS 2 号油 \\
比重 & $0.873\left(15^{\circ} \mathrm{C}\right.$ oil $/ 4^{\circ} \mathrm{C}$ water $)$ \\
粘度 & $9.6 \times 10^{-3} \mathrm{~Pa} \cdot \mathrm{s}\left(30^{\circ} \mathrm{C}\right), \quad 2.9 \times 10^{-3} \mathrm{~Pa} \cdot \mathrm{s}\left(75^{\circ} \mathrm{C}\right)$ \\
反応 & 中性 \\
流動点 & $-32.5^{\circ} \mathrm{C}$ \\
引火点 & $135^{\circ} \mathrm{C}$ \\
着火点 & $145^{\circ} \mathrm{C}$ \\
蒸留点 & $350^{\circ} \mathrm{C}$ \\
\hline
\end{tabular}

曲線を試料の物性を表-3 に示す．砂試料の締め固めの 影響を除くため，全試験で乾燥密度を統一した。

\section{（3）粘性係数と透油係数の関係}

Taylor は透過係数が流体の性質を表す粘性係数と密 度および多孔質媒体の性状を表す物理的透過係数 $K_{0}$ の 関係で表されることを示した ${ }^{42)}$.

$$
k=\frac{\rho g}{\mu_{l}} K_{0}
$$

ここで, $k$ : 透過係数 $(\mathrm{cm} / \mathrm{s}), \rho$ : 流体の密度 $\left(\mathrm{g} / \mathrm{cm}^{3}\right)$, $g$ : 重力加速度 $\left(\mathrm{cm} / \mathrm{s}^{2}\right), \mu_{l}$ : 流体の粘性係数 $(\mathrm{Pa} \cdot \mathrm{s}), K_{0}$ : 物理的透過係数 $\left(\mathrm{cm}^{2}\right)$.

式 (20) では，透過係数は通過する流体の性質と土試 料の性状により決定され，試料の性状が同一であれば, 透過係数は流体の単位体積重量に比例し, 粘性に反比 例することを示している．この式は一般に温度により 流体の粘性が変化する場合，あるいは 2 種類以上の流 体を取り扱う場合に用いられる。

図-6に油の温度を变化させて透油試験を行って求め た透過係数を示す. 縦軸に透油係数 $k_{\mathrm{oil}}$, 横軸に密度と 粘性係数との比 $\left(\rho_{\text {oil }} g / \mu_{\text {oil }}\right)$ として整理した. 図-6よ り両者には比例関係が見られる。試料の性状が同じ場 合には, 透油係数は油の粘性係数に反比例し, 密度に 比例することが確認された。 ちなみに，図-6 の直線の

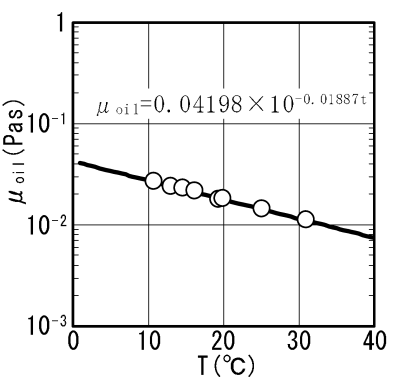

図-3 粘性係数と温度の関係

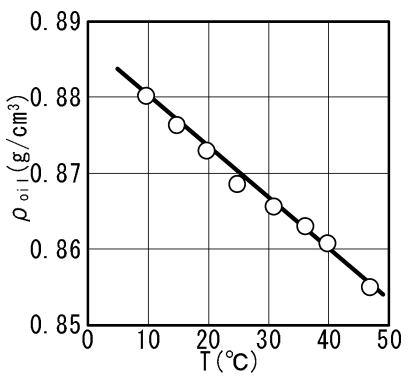

図-4 密度と温度の関係

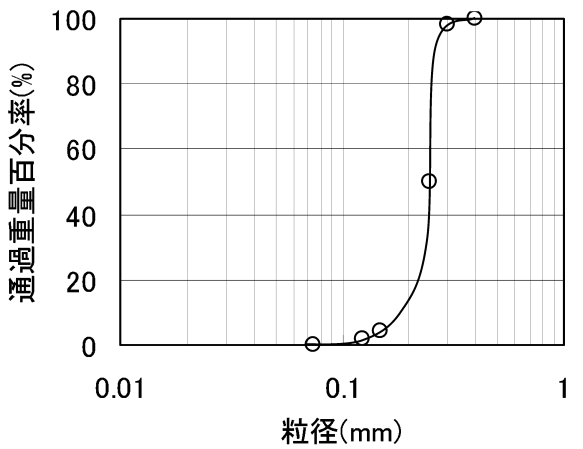

図-5 砂試料の粒度分布

表-3 砂試料の物性

\begin{tabular}{c|c|c|c|c}
\hline $\begin{array}{c}\text { 乾燥密度 } \\
\rho_{d}\left(\mathrm{~g} / \mathrm{cm}^{3}\right)\end{array}$ & $\begin{array}{c}\text { 土粒子の } \\
\text { 比重 }\end{array}$ & $\begin{array}{c}\text { 有効径 } \\
D_{10}\end{array}$ & $\begin{array}{c}\text { 均等係数 } \\
U_{C}\end{array}$ & $\begin{array}{c}\text { 曲率係数 } \\
U_{C}^{\prime}\end{array}$ \\
\hline 1.50 & 2.64 & 0.19 & 1.33 & 1.13 \\
\hline
\end{tabular}




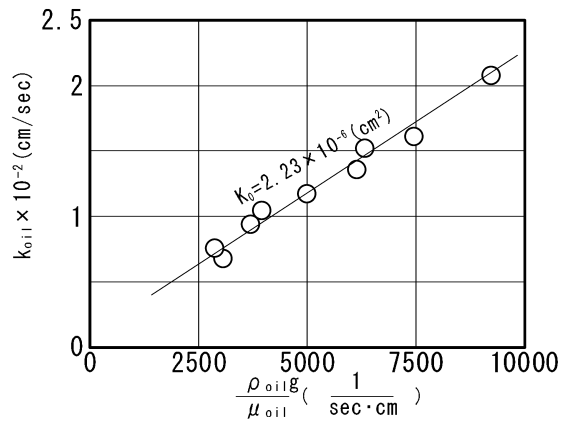

図-6 $\rho_{\mathrm{oil}} g / \mu_{\mathrm{oil}}$ と透油係数の関係

傾きである物理的透過係数 $K_{0}$ は $2.23 \times 10^{-6}\left(\mathrm{~cm}^{2}\right)$ と なることがわかる.

ここで, 物理的透過係数を求めることは, 浸透する 物質の粘性係数と密度を把握することによって, 物質 の飽和透水係数を推定することが可能となるという利 点がある.

\section{5. 瞬時水分計測法による鉛直一次元浸透実験}

\section{（1）実験の目的}

水の水分保持特性曲線の測定方法はすでに確立され ている ${ }^{43)}$. また，一般に水の体積含水率を測定する方 法には, 電気抵抗や誘電率の変化から測定する方法が ある. しかし，これらの方法を油と水と空気の三相系 の計測に適用することは困難である．また， RIを用い

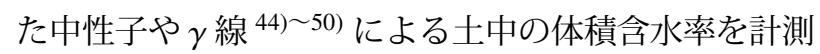
する方法がある. これらの中で中性子は, 中性子が水 分子に合うことによって熱中性子になり，それをカウ ントすることによって土中の水分量を計測する方法で あるため, 中性子では土中に含まれる油量を計測する ことは困難である ${ }^{48)}$. 一般に $\gamma$ 線は鉛等の遮蔽壁によ り線束を任意の幅に絞ることが容易であり, 測定点の 座標を正確に把握することができる利点を有する．ま た, 油, 水, 空気という三相系において, 浸潤相であ る水が土中水を移動しない範囲のわずかな飽和度であ る場合において, 不飽和地盤内の油の不飽和浸透特性 を把握する上で, 有効な手法と考えられる.ここでは, $\gamma$ 線計測器を用いた瞬時水分計測装置および圧力变換 器を用いて, 三相系の浸透流解析に必要となる相対透 油係数と飽和度, 毛管上昇高と飽和度の関係を求める 方法について示す.

\section{（2）鉛直一次元浸透実験装置}

試験容器は幅 $10 \mathrm{~cm}$, 深さ $7 \mathrm{~cm}$, 長さ $80 \mathrm{~cm}$ のアクリ ル製角柱を用いた。土試料は豊浦標準砂を用いた。流 体には表-2 と同じ油を用いた. 実験条件を表-4に示 す. 供試体の含水状態を飽和度が $0 \%$ の乾燥状態, 飽和 度が 10\%，20\%の湿潤状態の 3 ケースとした。

\begin{tabular}{l|c|c|c}
\multicolumn{4}{c}{ 表-4 実験条件 } \\
\hline 乾燥密度 $\rho_{d}\left(\mathrm{~g} / \mathrm{cm}^{3}\right)$ & \multicolumn{3}{|c}{1.50} \\
\hline 初期飽和度 $S_{w 0}(\%)$ & 0.0 & 10.0 & 20.0 \\
\hline 初期含水比 $W_{i}(\%)$ & 0.00 & 2.87 & 5.74 \\
\hline
\end{tabular}

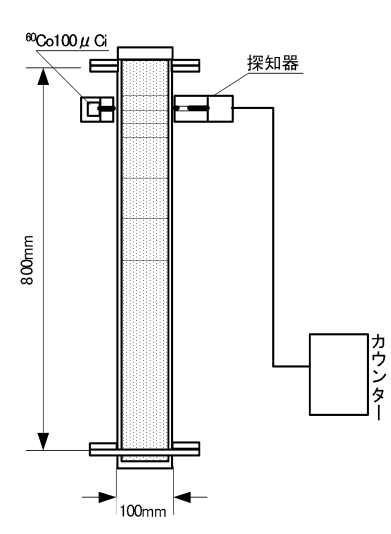

図-7 瞬時水分測定装置

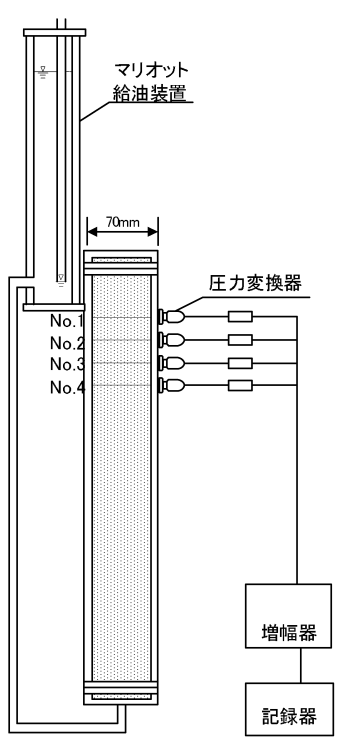

図-8 圧力変換器測定装置
図-7 に瞬時水分測定装置, 図-8 に圧力変換装置を 示す. $\gamma$ 線による瞬時水分計測法について簡単に説明 する.

1）油の含有量の計測については, $\gamma$ 線による.

2）油の毛管上昇高については, 圧力変換器のダイヤ フラムの前に油を注入して不飽和状態での土が 油を吸収しょうとする負の圧力を計測する.

\section{a) 浸潤実験の方法}

最初に供試体の初期含水比を $\gamma$ 線計測機により計測 した. 次に, 供試体の上部を大気圧状態に開放し, 下 部から一定へッド $(85 \mathrm{~cm})$ で給油を行う. 浸潤面が供 試体上面に達するまで行った。 計測事項はマリオット 給油装置の油面の時間的変化 $(H(t) \sim t)$, 浸潤面の時間 的変化 $\left(Z_{f}(t) \sim t\right)$ および供試体内の 4 つの測定点での 供試体中の体積液体含有率体率の時間的変化 $\left(\theta_{\mathrm{oil}} \sim t\right)$, 毛管上昇高の時間的変化 $\left(\phi_{\mathrm{oil}} \sim t\right)$ を測定する.

\section{b）排油実験の方法}

浸潤実験の終了後, 下部からの給油を停止して, 鉛 直一次元排油実験を行った. なお, 供試体の上部は大 気圧の状態に開放した。 供試体中の体積液体含有率の 時間的変化 $\left(\theta_{\mathrm{oil}} \sim t\right)$ および毛管上昇高の時間的変化を 測定する. 計測は排油開始より 720 分間行った.

\section{（3）有効間隙率の測定結果}

浸潤実験において，マリオット給水装置の油面の降 下量と浸潤面の位置を測定することにより, 有効間隙 率を算定することができる. 有効間隙率は式 (21) で求 


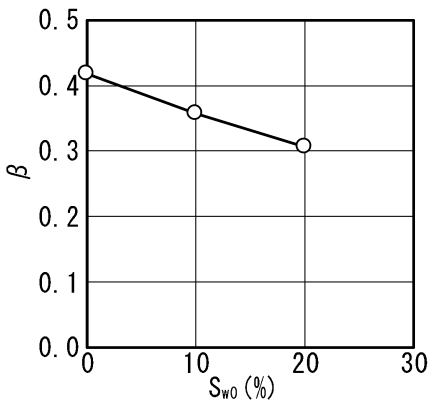

図-9 有効間隙率と初期飽和度の関係

表-5 VGM モデルのパラメータ

\begin{tabular}{c|c|c|c|c}
\hline$S_{w 0}(\%)$ & $S_{n r}(\%)$ & $k_{s}(\mathrm{~cm} / \mathrm{s})$ & $n$ & $m$ \\
\hline 0 & 10.0 & $2.00 \times 10^{-3}$ & 8.59 & 0.884 \\
\hline
\end{tabular}

表-6 LP モデルおよび He モデルのパラメータ

\begin{tabular}{c|c|c|c|c|c}
\hline$S_{w 0}(\%)$ & $S_{n r}(\%)$ & $S_{w r}(\%)$ & $k_{s}(\mathrm{~cm} / \mathrm{s})$ & $n$ & $m$ \\
\hline 10 & 10.0 & 0.0 & $2.00 \times 10^{-3}$ & 8.59 & 0.884 \\
\hline 20 & 10.0 & 0.0 & $2.00 \times 10^{-3}$ & 8.59 & 0.884 \\
\hline
\end{tabular}

まる。

$$
\beta=\frac{a}{A} \frac{H(t)}{Z_{f}(t)}
$$

ここで, $\beta$ : 有効間隙率, $A$ : 試料の断面積 $\left(\mathrm{cm}^{2}\right)$,

$a$ : マリオット給油装置の断面積 $\left(\mathrm{cm}^{2}\right)$,

$H(t)$ :マリオット給油装置の油面の降下量 $(\mathrm{cm})$,

$Z_{f}(t)$ : 浸潤面の位置 $(\mathrm{cm})$.

図-9 に有効間隙率と初期飽和度 $\left(S_{w 0}\right)$ の関係を示 す. 同図より, 初期飽和度が増加するにつれて, 有効 間隙率の值が小さくなっていることがわかる.

なお, この試験での $Z_{f}(t)$ の計測には油に蛍光染料 （ウラニン）を混合してその浸潤のフロントの挙動をブ ラックライト (紫外線) で計測した。

\section{（4）相対透油係数と飽和度の測定結果}

今回の実験では, 初期飽和度が $0 \%$ 場合には, 空気 と油の二相系であり，初期飽和度が 10\%，20\%の場合 には空気と油と水の三相系の問題となる.

まず，図-10に初期飽和度が 0\%の場合における相対 透油係数と油の有効飽和度の関係を示す，また，同図 に式 (18) で計算される VGM モデルでの推定線を併記 した. 表-5に VGM モデルのパラメータを示す.

図-11 に初期飽和度が 10\%，20\%の場合の相対透油 係数と液体飽和度の関係を示す。また, 同図に式 (19c) による LP モデルおよび式 (19d) による He モデルの推 定線を併記した．表-6に各パラメータを示す．

初期飽和度が 10\%では，実験結果にばらつきがある が，概ね推定線と一致している。 しかし，初期飽和度 が 20\%では，実験結果は推定線より下回っている.

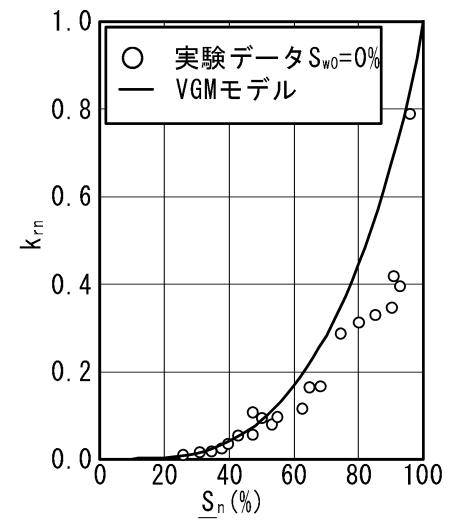

図-10 相対透油係数と有効飽和度の関係 （空気一油二相系）

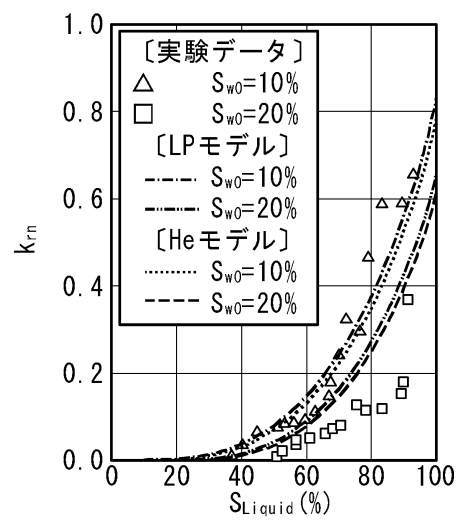

図-11 相対透油係数と飽和度の関係（三相系）

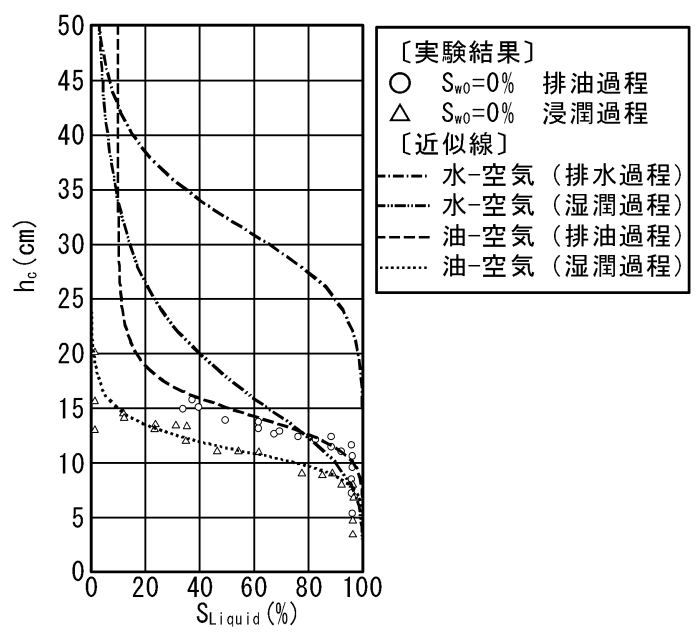

図-12 毛管上昇高と飽和度の関係（二相系）

（5）毛管上昇高と飽和度の測定結果

図-12 に初期飽和度が 0\%の場合における毛管上昇高 と液体飽和度の関係を示す。同図には, 式 (5)より計 算される VG モデルによる推定線を併記する. 表-7 に 推定線のパラメータを示す。

今回の実験は浸潤過程を経て, 排油過程の実験を行っ た. 初期飽和度が 0\%の場合において, 油の最大飽和度 は，湿潤過程で約 97\%である，湿潤過程において，供 試体の底部から油を浸透させたが，供試体内には $3 \%$ 程 度の空気が閉じ込められたことがわかる. 
表-7 VG モデルのパラメータ（二相系）

\begin{tabular}{ccccc}
\hline \multicolumn{2}{c}{ ケース } & $S_{\alpha r}(\%)_{(\alpha=w, n)}$ & $n$ & $\alpha$ \\
\hline 空気一水 & 排油過程 & 0.0 & 8.59 & 0.032 \\
\hline 空気一水 & 湿潤過程 & 0.0 & 4.01 & 0.062 \\
\hline 空気一油 & 排油過程 & 10.0 & 8.59 & 0.070 \\
\hline 空気一油 & 湿潤過程 & 10.0 & 8.59 & 0.090 \\
\hline
\end{tabular}

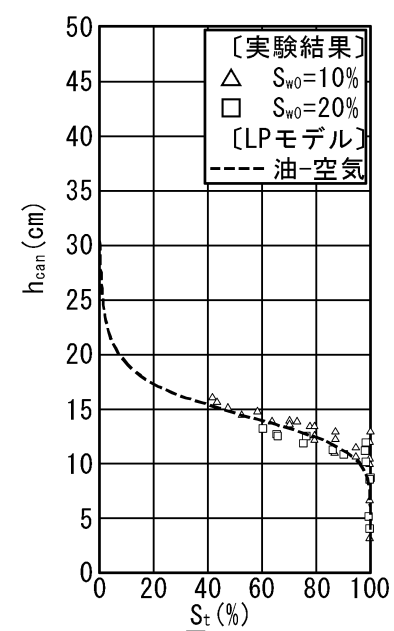

[排油過程]

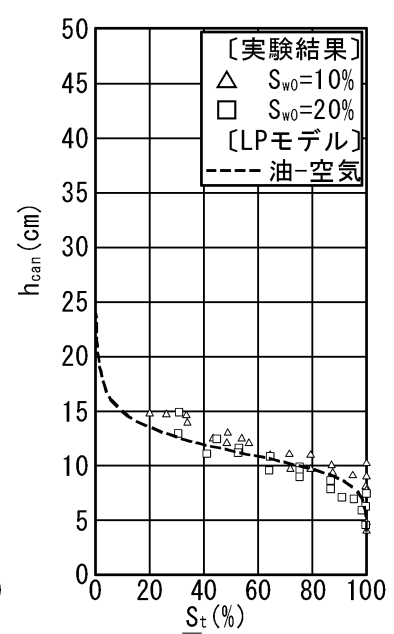

[湿潤過程]
図-13 毛管上昇高と飽和度の関係（三相系）

図-13 に初期飽和度が 10\%, 20\%での三相系における 毛管上昇高と見かけ液体飽和度の関係を示す．見かけ 液体飽和度 $\underline{S}_{t}$ は式 $(9 \mathrm{~b})$ より求めた. LP モデルのパラ メータは二相系と同じ值を用いた。排油過程では, 推 定線と実験結果はほぼ一致していることがわかる。一 方, 湿潤過程では, 飽和度が低い範囲では, 実験結果 が推定線より大きくなっていることがわかる.

本研究では, $\gamma$ 線による瞬時水分計測法と圧力変換 器を用いて, 油が供試体を浸透する際の毛管上昇高と 飽和度の関係, 相対透油係数と飽和度の関係を求めた. その結果, 相対透油係数と飽和度の関係は, 乾燥状態 の実験では, 空気一油の二相系となり, VGM モデル を適用できることがわかった。一方, 飽和度が $10 \%$, 20\%の水を含む湿潤状態の実験では, LP モデルを適用 できることが確認された．また, 湿潤状態の実験より, 水分量が多くなると, 油の有効間隙率が小さくなり, 相 対透油係数が小さくなることがわかった．これらの実 験より, $\gamma$ 線による瞬時水分計と圧力変換器を用いた 実験装置により, 解析に必要となる相対透過係数と飽 和度の関係を精度良く求めることが可能であることが 確認された.

毛管上昇高と飽和度の関係は, 乾燥状態の実験では 空気一油の二相系となり, VG モデルを適用できるこ とが確認された． 飽和度が 10\%，20\%の水を含む湿潤 状態の実験では, 空気一油一水の三相系での実験とな る. この実験より得られる毛管上昇高と飽和度の関係
表-8ＬP モデルのパラメータ（三相系）

\begin{tabular}{ccccc}
\hline \multicolumn{2}{c}{ ケース } & $S_{\alpha t}(\%)$ & $n$ & $\alpha$ \\
\hline$S_{w 0}=10 \%$ & 排油過程 & 7.3 & 8.59 & 0.070 \\
\hline$S_{w 0}=10 \%$ & 湿潤過程 & 7.6 & 8.59 & 0.090 \\
\hline$S_{w 0}=20 \%$ & 排油過程 & 8.8 & 8.59 & 0.070 \\
\hline$S_{w 0}=20 \%$ & 湿潤過程 & 9.1 & 8.59 & 0.090 \\
\hline
\end{tabular}

表-9 供試体の組み合わせ

\begin{tabular}{l|c|c|c|c}
\hline 乾燥密度 $\rho_{d}\left(\mathrm{~g} / \mathrm{cm}^{3}\right)$ & \multicolumn{4}{|c}{1.50} \\
\hline 初期飽和度 $S_{w 0}(\%)$ & 0.0 & 10.0 & 20.0 & 30.0 \\
\hline 初期含水比 $W_{i}(\%)$ & 0.00 & 2.87 & 5.74 & 8.61 \\
\hline
\end{tabular}

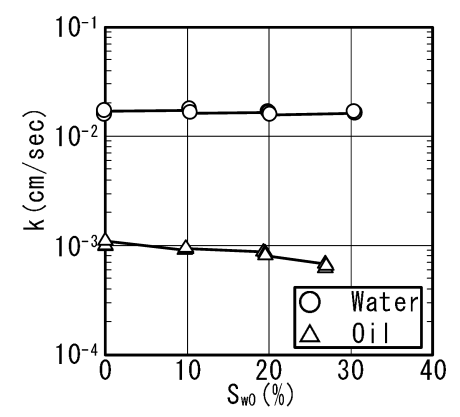

図-14 透油・透水係数と初期飽和度の関係

は, LP モデルに基づき空気一油間の毛管上昇高と液体 有効飽和度の関係を適用できることが確認された。

\section{6. 変水位透水試験装置による二相系の実験}

\section{（1）初期飽和度の異なる試料の飽和透水・透油係数}

変水位透水試験は, 土の飽和状態の透水係数を求め るため試験で良く使われる室内試験法である。ここで は, 初期飽和度を変えた供試体に対して, 水および油を 飽和状態で浸透させて, 透水・透油係数を求めた. 実 験の条件を表-9 に示す．供試体内の飽和度分布を一様 に保つ必要があるため, 初期飽和度は 0〜30\%の範囲 で実施した。

図-14に透水・透油係数と初期飽和度の関係を示す. この実験より, 飽和時の透水係数は $1.61 \times 10^{-2}(\mathrm{~cm} / \mathrm{s})$, 透油係数は $1.01 \times 10^{-3}(\mathrm{~cm} / \mathrm{s})$ が求められた. 水の場 合には, 初期飽和度による透水係数の変化はほとんど ない.

一方, 油の場合には, 初期飽和度の増加により透油 係数が低下することがわかる. これは, 初期飽和度が 大きくなると通過可能な断面の大きさが狭くなり, 油 が浸透するための有効間隙率が小さくなることが原因 であると考えられる.

図-15 に透油係数と透水係数の比と初期飽和度の関 係を示す. 初期飽和度が大きくなると透油係数と透水 係数の比が小さくなることがわかる. この図のように, 


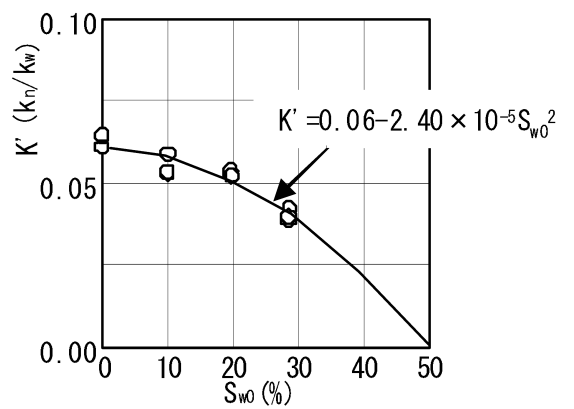

図-15 透油係数/透水係数と初期飽和度の関係

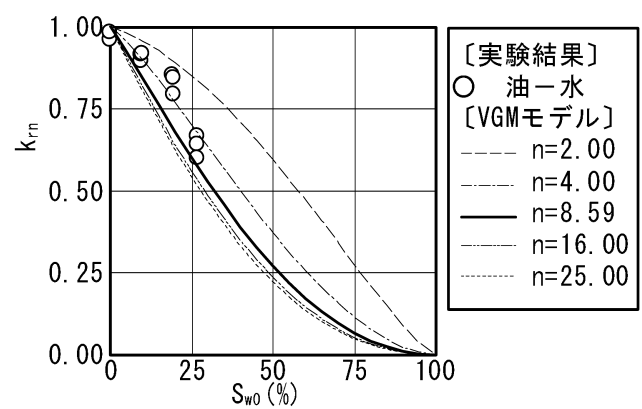

図-16 相対透油係数と初期飽和度の関係

水を含む地盤に透油が浸透する場合には, 油の浸透性 は地盤の飽和度に影響を受け, 地盤の土中水の飽和度 と透油係数の間には非線形の関数関係が成立するもの と考えられる.

\section{（2）相対透油係数と初期飽和度の関係}

この実験では, 通油により, 供試体の内部を水と油で 飽和することから, 油と水による二相系の実験であると 仮定して，図-16に式(18b) より計算されるVGM モデ ルの推定線を併記した。瞬時水分計測法により, VGM モデルのパラメータ $n$ は 8.59 と推定された. 図-16よ り, 実験結果は, 初期飽和度が $25 \%$ までは $n=4.0$ で近 似され, $25 \%$ 以上では, 透油係数比が低減し, $n=8.59$ に近づくことがわかる．この場合にも VGM が適用さ れると考えても良い.

\section{GAM モデルによる水平一次元浸透実験}

GAM モデルでは，一次元カラムの上流端を一定水 位にして水を浸透させて, 浸潤面の位置一流入流量一 時間の関係を測定することによって, 有効間隙率, 透 水係数, 毛管上昇高を求めることができる ${ }^{51)}$. GAM モデルの試験装置は簡便であるためいろいろなところ で実施できる利点がある。ここでは, 油-空気-水系に おいて GAM モデルを応用した手法を提案するととも に，その適用性を検証する．また，鉛直実験と水平実 験を行い, 両者の相違についても比較検討する.

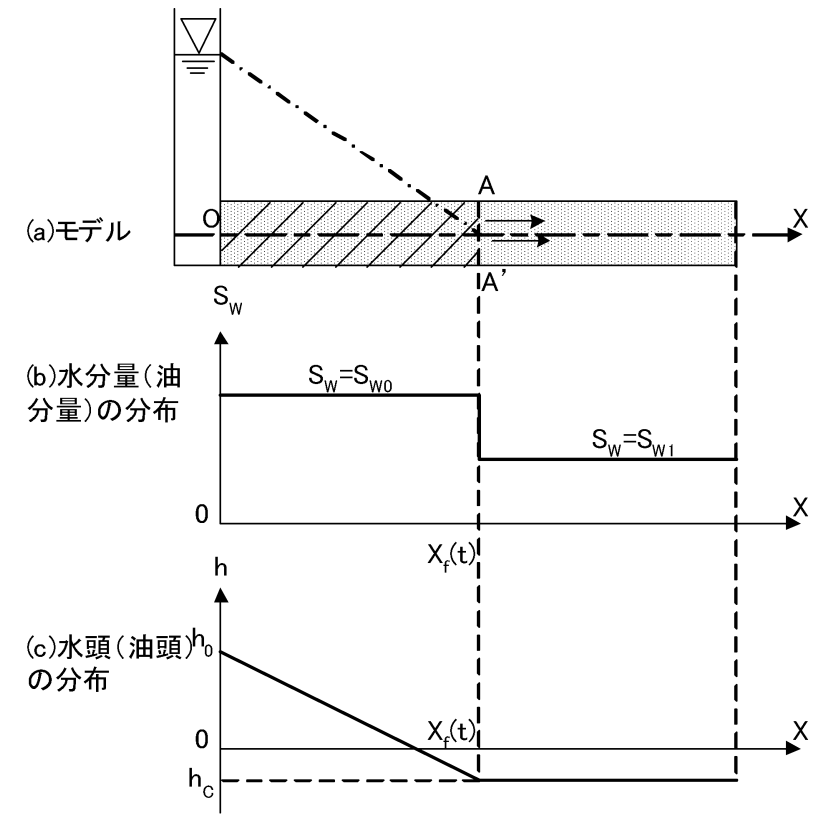

図-17 水平一次元の浸透モデル

\section{（1）水平一次元浸透実験解析法}

不飽和土カラムにおける流体の浸透現象を支配する 水理定数である透油・透水係数, 毛管上昇高および有効 間隙率を水平一次元浸透実験より求める方法を図-17 に 示す. 土の供試体の左端 $(X=0)$ から水を全水頭 $\left(h_{0}\right)$ を一定に浸透させ, 浸潤前線 $\left(\mathrm{AA}^{\prime}\right)$ の位置 $\left(X=X_{f}(t)\right)$ とその進行を測定する.

この現象の解析式は GAM より次のように導かれる.

$$
\beta \frac{d x}{d t}=k \frac{h_{0}+h_{c}}{x}
$$

ここで, $h_{c}$ : 浸潤前線での毛管上昇高 $\left(X_{f}(t)\right.$ の点での 毛管上昇高), $\beta$ : 有効間隙率, $k$ : 透水係数, または透油係数.

一定圧力での水平一次元浸透実験により測定する項 目は, 以下の 2 つの関係である.

1）浸潤面の時間的変化 : $X_{f}(t) \sim t$ の関係

2）総流入量の時間的変化 : $q(t) \sim t$ の関係

ここで, $X_{f}(t)$ は浸潤前線の座標, $q(t)$ は総流入量である.

上記 1)，2）それぞれについて解析を行うと 2 種類 の解析法が得られる.

式 (22) を初期条件 $t=0$ において $X_{f}(0)=0$ で積分 すると次式が得られる.

$$
X_{f}^{2}(t)=2 \frac{k}{\beta}\left(h_{0}+h_{c}\right) \cdot t
$$

\section{a) $X_{f}^{2}(t) \sim t$ の関係による解析}

本実験では $t=0$ 時の $X_{f}(0)=0$ から $t=t_{1}$ 時の $X_{f}\left(t_{1}\right)=X_{f 1}$ まで一定水位 $h_{01}$ に保ち, $t=t_{2}$ 時に注入 側の全水頭を瞬時に $h_{02}$ に急変化させて, それ以降 $h_{02}$ に保つ. 縦軸に $X_{f}^{2}(t)$, 横軸に $t$ をとると図-18 のグラ 


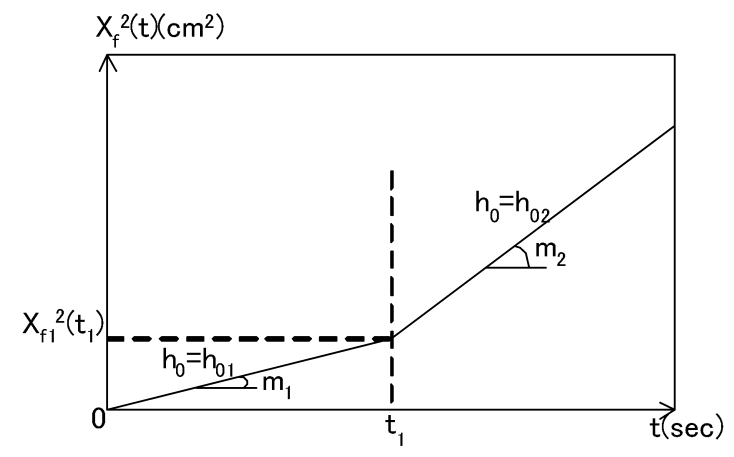

図-18 $X_{f}^{2}(t)$ と $t$ の関係 $\left(h_{01}<h_{02}\right)$

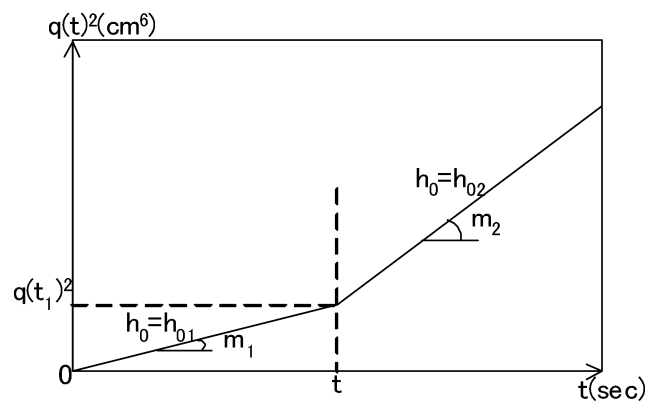

図-19 $q^{2}(t)$ と $t$ の関係 $\left(h_{01}<h_{02}\right)$

フとなる. 同グラフより水頭 $h_{01}, h_{02}$ に対応する傾き $m_{1}, m_{2}$ を求めると, 次式で表される.

$$
m_{1}=2 \frac{k}{\beta}\left(h_{01}+h_{c}\right), \quad m_{2}=2 \frac{k}{\beta}\left(h_{02}+h_{c}\right)
$$

(24a,b)

式(24)より $k / \beta$ および $h_{c}$ の值が次式より求められる.

$$
\frac{k}{\beta}=\frac{m_{1}-m_{2}}{2\left(h_{01}-h_{02}\right)}, \quad h_{c}=\frac{m_{1} h_{02}-m_{2} h_{01}}{m_{2}-m_{1}}
$$

\section{b) $q(t) \sim t(\mathrm{sec})$ の関係による解析}

浸潤面が $X_{f}(t)$ 進行した時の総流入量を $q(t)\left(\mathrm{cm}^{3}\right)$ と すると, $X_{f}(t)$ は式 (26a) より式 (26b) のように求めら れる. 式 (26b) を式 (23) に代入し, $q(t)$ について整理 すると, 式 (27) で表される.

$$
\begin{array}{r}
q(t)=\beta \cdot X_{f}(t) \cdot A, \quad X_{f}(t)=\frac{q(t)}{\beta \cdot A} \\
q^{2}(t)=2 \cdot k \cdot \beta \cdot A^{2}\left(h_{0}+h_{c}\right) \cdot t
\end{array}
$$

ここで, $A$ : 土中の断面積 $\left(\mathrm{cm}^{2}\right)$.

本実験では定水頭 $h_{0}$ を 2 段階に変化させて浸透試験 を行い, その結果を縦軸に $q^{2}(t)$, 横軸に計測時間 $t$ を とり, グラフに表すと図-19 となる. 同図より, 水頭 $h_{01}, h_{02}$ に対応する傾き $m_{1}, m_{2}$ を求めると, それらは 式 (28a), (28b) になる.

$$
\begin{aligned}
& m_{1}=2 \cdot k \cdot \beta \cdot A^{2}\left(h_{01}+h_{c}\right) \\
& m_{2}=2 \cdot k \cdot \beta \cdot A^{2}\left(h_{02}+h_{c}\right)
\end{aligned}
$$

したがって, $k \cdot \beta$ および $h_{c}$ が次式より, 求められる.

$k \cdot \beta=\frac{1}{2 A^{2}} \frac{m_{1}-m_{2}}{h_{01}-h_{02}}, \quad h_{c}=\frac{m_{1} h_{02}-m_{2} h_{01}}{m_{2}-m_{1}}$

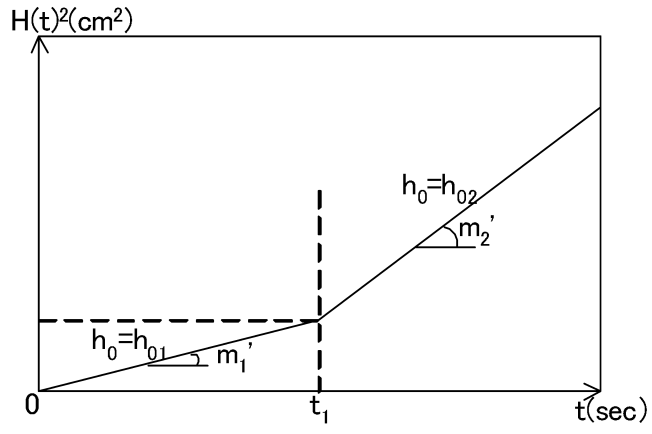

図-20 $H^{2}(t)$ と $t$ の関係 $\left(h_{01}<h_{02}\right)$

実験では, 総流入量 $q(t)$ の時間的変化をマリオット 給水装置の水面降下量 $H(t)$ を測定すると求められる. $q(t)$ と $H(t)$ の関係は次式で表される.

$$
q(t)=a \cdot H(t)
$$

ここで, $a$ : マリオット給水装置の断面積 $\left(\mathrm{cm}^{2}\right)$.

式(30)を式(27)に代入し整理すると次式で表される.

$$
H^{2}(t)=2 \cdot k \cdot \beta \cdot \frac{A^{2}}{a^{2}}\left(h_{01}+h_{c}\right) \cdot t
$$

したがって, 式 (31) より, 図-19を図-20 のように 書き換えられる. また, 式 (28), 式 (29) はそれぞれ式 (32) および式 (33)のように表される.

$$
\begin{gathered}
m_{1}^{\prime}=2 \cdot k \cdot \beta \frac{A^{2}}{a^{2}}\left(h_{01}+h_{c}\right) \\
m_{2}^{\prime}=2 \cdot k \cdot \beta \frac{A^{2}}{a^{2}}\left(h_{02}+h_{c}\right) \\
k \cdot \beta=\frac{1}{2} \cdot \frac{a^{2}}{A^{2}} \cdot \frac{m_{1}^{\prime}-m_{2}^{\prime}}{h_{01}-h_{02}} \\
h_{c}=\frac{m_{1}^{\prime} h_{02}-m_{2}^{\prime} h_{01}}{m_{2}^{\prime}-m_{1}^{\prime}}
\end{gathered}
$$

ここで，これらを整理すると，2段階一定圧注入量 により式 (25) から $k / \beta$ が求まり, 式 (33)より $k \cdot \beta$ が 求まる.これらは同一の試料に対して得られた值であ るため, $k / \beta=C_{1}, k \cdot \beta=C_{2}$ とすると, $k$ および $\beta$ は 次式で計算される.

$$
k=\sqrt{C_{1} \cdot C_{2}}, \quad \beta=\sqrt{\frac{C_{2}}{C_{1}}}
$$

(34a,b)

\section{c）有効間隙率 $\beta$ のもう一つの求め方}

有効間隙率は式 (34b) によって求められるが, 室内 試験でモールドが透明であれば油の浸潤面が計測でき る. これより $\beta$ の值は, 以下の方法によっても算定で きる.

同一時間における浸潤面 $X_{f}(t)(\mathrm{cm})$ と総流入量 $q(t)$ $\left(\mathrm{cm}^{3}\right)$ の関係は式 (26a) で表される. したがって，式 (26a)を有効間隙率について整理すると式 (35a) で表さ れる.

実験では，流入量はマリオット給水装置で計測する. 


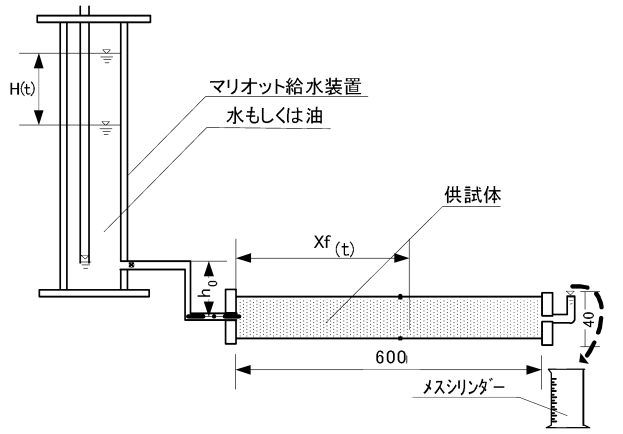

図-21 水平一次元浸透実験試験器具 (単位: $\mathrm{mm}$ )

表-10 供試体の初期条件

\begin{tabular}{l|c|c|c|c|c|c}
\hline 乾燥密度 $\rho_{d}\left(\mathrm{~g} / \mathrm{cm}^{3}\right)$ & \multicolumn{7}{|c}{1.50} \\
\hline 初期飽和度 $S_{w 0}(\%)$ & 0.0 & 10.0 & 20.0 & 30.0 & 40.0 & 50.0 \\
\hline 初期含水比 $W_{i}(\%)$ & 0.00 & 2.87 & 5.74 & 8.61 & 11.5 & 14.4 \\
\hline
\end{tabular}

したがって, 式(30)を式(35a)に代入すると式(35b)で 表される.

$$
\beta=\frac{1}{A} \cdot \frac{q(t)}{X_{f}(t)}, \quad \beta=\frac{a}{A} \cdot \frac{H(t)}{X_{f}(t)}
$$

有効間隙率 $\beta$ は式 (35b)において縦軸に $H(t)$, 横軸に $X_{f}(t)$ をとり, そのグラフの勾配 $m^{\prime \prime}$ を求めると式 (36) より求められる.

$$
m^{\prime \prime}=\frac{H(t)}{X_{f}(t)}, \quad \beta=\frac{a}{A} \cdot m^{\prime \prime}
$$

\section{（2）水平一次元の実験装置および実験方法}

実験装置を図-21 に示す。定水位給水装置にはマリ オット給水装置を用いた。.土試料は比較的取り扱いや すい豊浦標準砂を用いた，乾燥密度は同一とし，初期 飽和度が 0〜 50\%の範囲で実験を行った．表-10 に実験 の条件を示す．実験は供試体の一端を大気圧に開放し, 流入側の供試体の左端での水頭を $h_{01}=20 \mathrm{~cm}$ の一定 水頭で作用させ, 約 $30 \mathrm{~cm}$ 程度浸潤した時点で水頭を $h_{02}=40 \mathrm{~cm}$ の一定水頭に急変化させた. 実験では, 浸 潤面の時間的変化 $\left(X_{f}(t)-t\right)$, マリオット給水装置の水 面の時間的変化 $(H(t)-t)$ を計測した. なお, 本実験で は浸潤終了後も給水を行い, 定常状態になるまで流出 流量を計測して, 一次元の飽和の透水係数, 透油係数 を求めた。

\section{（3）実験結果および考察}

\section{a）浸透実験の妥当性について}

実験測定結果として, 図-22 (a), (b) に $X_{f}^{2}(t)$ と $t$ の 関係，図-23 (a), (b) に $H^{2}(t)$ と $t$ の関係を示す。初期 飽和度が 20\%以下の試料では, 図-22 における $X_{f}^{2}(t)$ と $t$ および図-23における $H^{2}(t)$ と $t$ の間には，それぞれ 明確な直線関係が得られていることより, 浸潤面の前

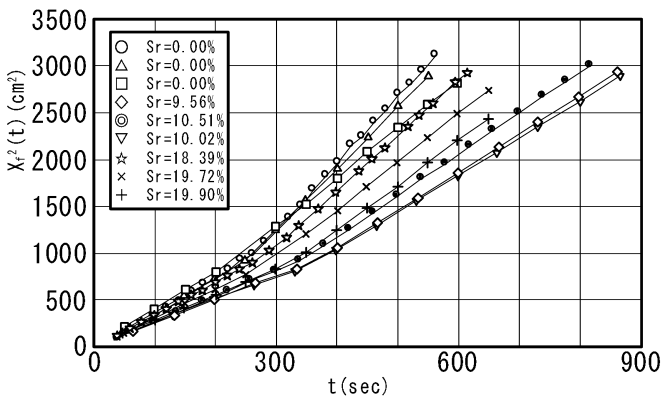

図-22 (a) $X_{f}^{2}(t)$ と $t$ の関係（対象流体：水）

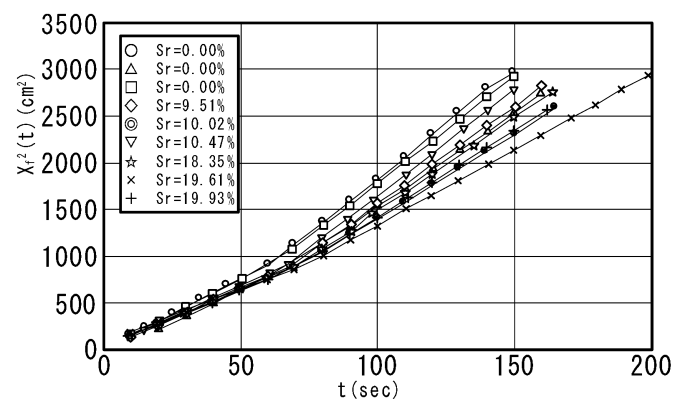

図-22 (b) $X_{f}^{2}(t)$ と $t$ の関係（対象流体：油）

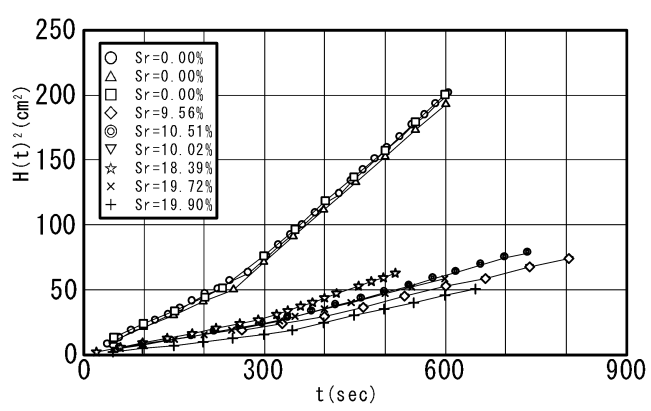

図-23 (a) $H(t)^{2}$ と $t$ の関係（対象流体：水)

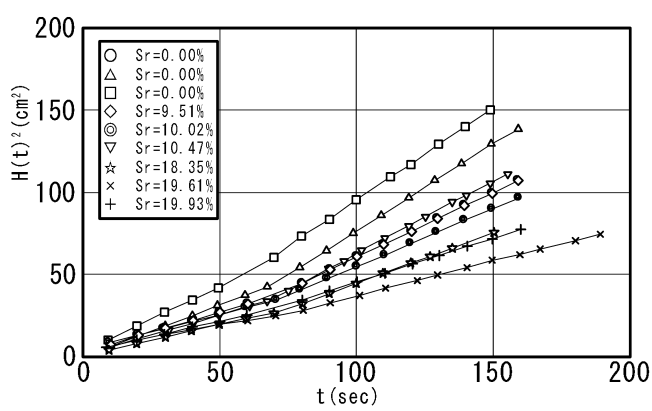

図-23 (b) $H(t)^{2}$ と $t$ の関係（対象流体：油）

後で含水比（含油比）が急変する全水頭の分布は直線 的に変化する GAM モデルの仮定が妥当であると判断 される。

図-24 (a), (b), (c) に $H(t)$ と $X_{f}(t)$ の関係を示す. $H(t)$ と $X_{f}(t)$ の関係では, 図-24 (a) より水の場合には, 初 期飽和度 $20 \%$ まで $H(t)$ と $X_{f}(t)$ の間に比例関係が成立 することが認められた. 図-24 (b) および図-24 (c)よ り油の場合には, 初期飽和度が約 50\%の值でも $H(t)$ と $X_{f}(t)$ の間に比例関係が認められた. 油の場合には, 高 含水状態でも水と油が置換して, 油が一様の飽和度を 


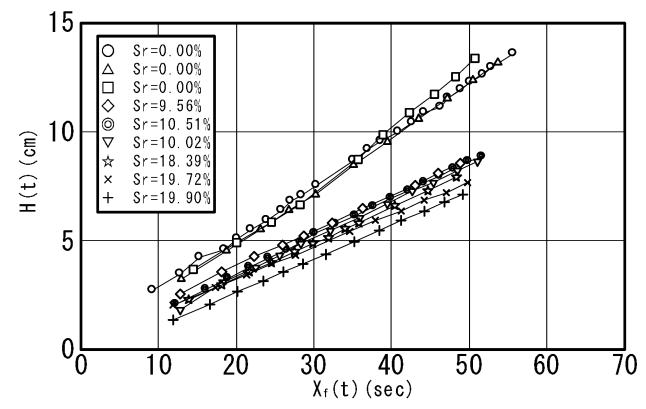

図-24 (a) $H(t)$ と $X_{f}(t)$ の関係（対象流体：水）

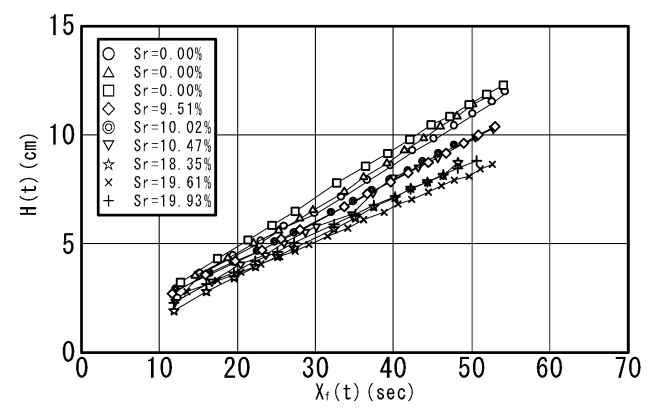

図-24 (b) $H(t)$ と $X_{f}(t)$ の関係（対象流体：油, $S_{r}<20 \%$ )

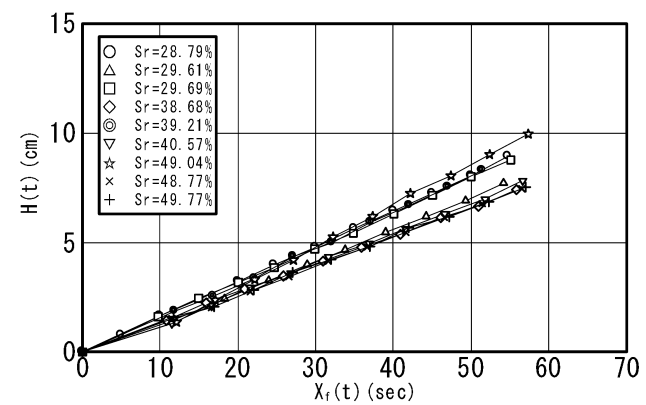

図-24 (c) $H(t)$ と $X_{f}(t)$ の関係（対象流体：油, $S_{r} \geqq 20 \%$ )

持って浸潤するため, 高含水状態でも GAM 仮定が成 立したものと推測される.

\section{b）透水・透油係数，有効間隙率と飽和度の関係}

水平一次元浸透実験より得られた透水・透油係数と 初期飽和度の関係を図-25 に示す. 透水係数 $k_{1}$, 有効 間隙率 $\beta_{1}$ は式 (34a), 式 (34b) より求めた值である. 透 水係数 $k_{S}$, 有効間隙率 $\beta_{S}$ は動水勾配および定常流量 より次式より算定した.

$$
k_{S}=\frac{Q}{i \cdot A \cdot t}, \quad \beta_{S}=\frac{Q_{1}-Q_{2}}{A \cdot L}
$$

ここで, $k_{S}$ : 定常浸透状態における透油・透水係数 $(\mathrm{cm} /$ $\mathrm{sec}), \beta_{S}$ : 定常浸透状態における有効間隙率, $Q$ : 流出量 $\left(\mathrm{cm}^{3}\right), I:$ 動水勾配, $A:$ 試料の断 面積 $\left(\mathrm{cm}^{2}\right), T$ : 流出時間 $(\mathrm{sec}), Q_{1}$ : 定常浸 透状態になるまでの試料内の総流入量 $\left(\mathrm{cm}^{3}\right)$, $Q_{2}:$ 定常浸透状態になるまでの試料からの総 流出量 $\left(\mathrm{cm}^{3}\right)$.

図-25 より，透水係数は初期飽和度 10～50\%の湿潤 状態よりも初期飽和度 $0 \%$ の乾燥状態において少し大

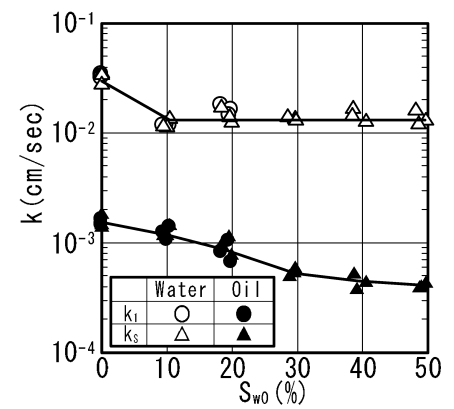

図-25 透水係数と初期飽和度の関係

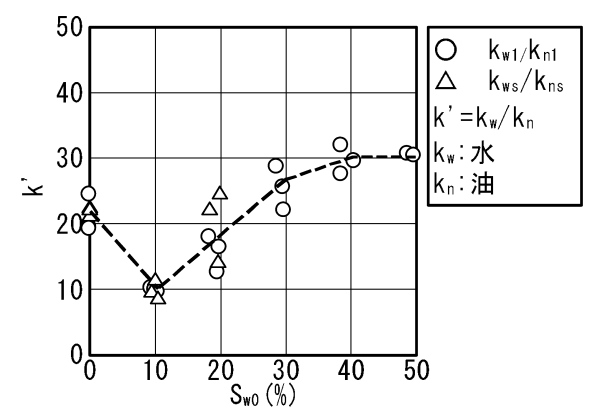

図-26 透水係数/透油係数と初期飽和度の関係

きいことがわかる．これは, 豊浦標準砂のように粒子 が均質な砂は, 水を含むことにより, 土粒子の再配置 が起こり, 有効間隙率が小さくなることによると考え られる. 透油係数は水の初期飽和度が $30 \%$ までは, 初 期飽和度の増加とともに減少し, 初期飽和度が 40\%以 上では，ほぼ一定であることがわかる.

図-25の結果より求められた透水係数と透油係数の 比 $\left(k^{\prime}=k_{w} / k_{n}\right)$ と初期飽和度の関係を図-26に示す. 初 期飽和度が $0 \sim 10 \%$ 範囲では, $k^{\prime}$ は低下している. 初 期飽和度が 10〜30\%の範囲では， $k^{\prime}$ は初期飽和度が高 くなるほど漸増している．初期飽和度 30～40\%の範囲 では $k^{\prime}$ は増加割合が低下し，初期飽和度が 40～50\%の 範囲ではほとんど変化がない.

透油実験では, 初期飽和度 30\%以上で水の流出が確 認されたことから, 初期飽和度 30\%以上の透油係数は, 油と水の混合流体の透水性を示している. 初期飽和度 $30 \%$ 以上の透油係数が一定となる理由は空気, 油, 水 という三相系の中で最も湿潤性の大きい水の移動によ る影響が顕著に現れているためであると推測される。

図-27 に有効間隙率 $\beta$ と間隙率 $\phi$ の比 $(\beta / \phi)$ と初期 飽和度の関係を示す. 水の場合には, 有効間隙率は初 期飽和度の増加とともに減少する．油の場合には，有 効間隙率は初期飽和度が 0〜 20\%の範囲では, 初期飽 和度の増加とともに減少するが，初期飽和度が $30 \%$ 以 上になると，ほぼ一定值となる。これは，初期飽和度 が 30\%以上では，水が移動し，流出したことによる影 響を受けているものと考えられる.

残留飽和度を無視すると, 次式より液体飽和度を求 めることができる. 


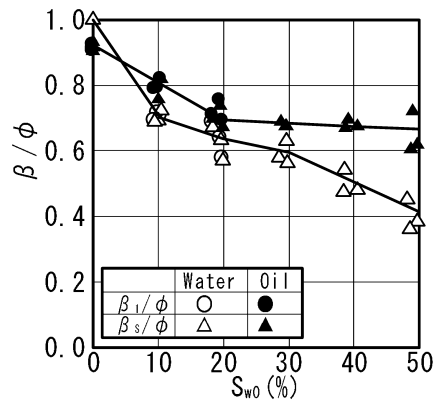

図-27 $\beta / \phi$ と初期飽和度の関係

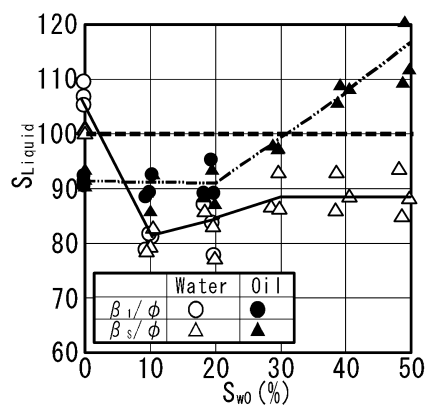

図-28 液体飽和度と初期飽和度の関係

$$
S_{\text {Liquid }}=\beta / \phi+S_{w 0}
$$

ここで, $S_{\text {Liquid }}$ : 液体飽和度, $\beta$ : 浸透流体の有効間隙 率, $\phi$ : 間隙率.

図-28 に液体飽和度と初期飽和度 $S_{w 0}$ の関係を示す. 水の場合には, 乾燥状態の実験では, 液体飽和度は概 ね 100\%であることがわかる. 湿潤状態の実験では, 初 期飽和度が 10〜 20\%の範囲では, 液体飽和度が 78〜 $86 \%$ 範囲である. 初期飽和度が $30 \%$ 以上では, 液体 飽和度は 85～92\%の範囲である. 湿潤状態の実験では, 間隙に封入されている空気が残存する不飽和状態での 実験であることがわかる.

油の場合には, 初期飽和度が 0〜20\%では, 液体飽 和度は 85〜93\%の範囲でほとんど変化ない. 初期飽和 度が 30\%以上では, 液体飽和度は初期飽和度の増加と 共に増加している．初期飽和度が $40 \%$ 以上では, 液体 飽和度は 108〜 120\%となる. 初期飽和度が 30\%以上で は, 式 (37b) より流入量と流出流量の差から, 有効間 隙率 $\beta$ を求めている. 流出量には油だけでなく, 水も 含まれているため, 有効間隙率 $\beta$ が計算上大きくなり, 飽和度が $100 \%$ 以上となった.

\section{c）毛管上昇高と初期飽和度の関係}

図-29 (a), (b) に毛管上昇高 $h_{c}$ と初期飽和度 $S_{w 0}$ の関 係を示す. 図中の $k / \beta$ は式 (25b) より求めた $h_{c}$ の值, $k \cdot \beta$ は式 $(29 \mathrm{~b})$ より求めた $h_{c}$ の值を示す.

図-29 (a)より，水の毛管上昇高は初期飽和度が 0\%で $3.9 \sim 7.8 \mathrm{~cm}$, 初期飽和度が $10 \%$ で $11.2 \sim 19.1 \mathrm{~cm}$, 初期 飽和度が $20 \%$ で $1.2 \sim 10.1 \mathrm{~cm}$ である. このように, 水 の毛管上昇高は初期飽和度が $10 \%$ 一番高く, 初期飽

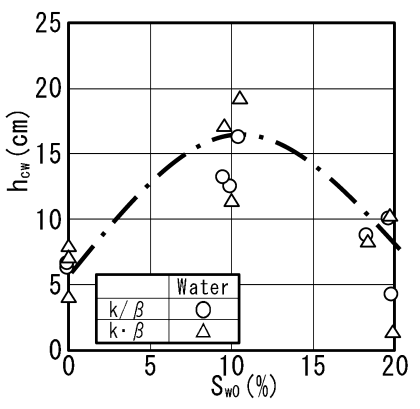

(a) 流体：水

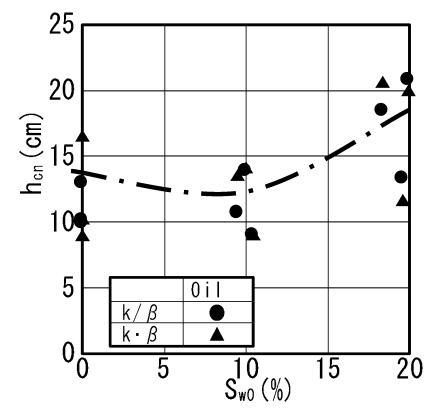

(b) 流体：油
図-29 毛管上昇高〜初期飽和度の関係

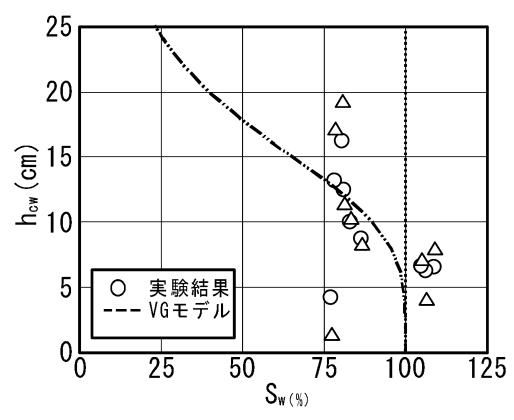

図-30 毛管上昇高〜水の飽和度の関係

和度が 0\%および 20\%で低く， 凸形状の傾向にある.

図-29 (b) より, 油の毛管上昇高は初期飽和度が $0 \%$ で 8.8〜 $16.4 \mathrm{~cm}$, 初期飽和度が $10 \%$ で $8.9 \sim 13.9 \mathrm{~cm}$ で, 初 期飽和度が 20\%で 11.5〜20.7 cm である. このように， 油の毛管上昇高は初期飽和度が 0〜 10\%の範囲では同 程度である. 水と異なり初期飽和度が $20 \%$ で毛管上昇 高が一番高いことがわかる.

毛管上昇高と式 (36) より求めた水の飽和度との関係 およびVG モデルによる推定線を図-30 に示す．実験 結果はばらついているが, 飽和度が小さくなると毛管 上昇高が大きくなる傾向があることおよび VG モデル による推定線の上下にばらついていることがわかる.

図-31 (a), (b) に毛管上昇高と油の飽和度の関係を示 す. 同図には, 湿潤過程における二相系の VG モデル による推定線および三相系における LP モデルによる空 気一油系の毛管上昇高 $h_{c a n}$ の推定線を併記する. 図-31 (a)より, GAM モデルにより計算される毛管上昇高は VG モデルおよびLP モデルの推定線よりも大きいこと がわかる.

湿潤状態にある供試体中に油が浸透する場合, 浸潤 面では油は水と空気のどちらにも接触することを考え ると, GAM モデルによる毛管上昇高は, 油が空気と接 触する時の毛管圧力と油が水と接触する毛管圧力の両 方の合算値であると考えられる. 図-31 (b) には空気一 油間の毛管上昇高 $h_{c a n}$ と油一水間の毛管上昇高 $h_{c n w}$ を 加えて, 毛管上昇高と飽和度の関係を示す. LP モデル で計算される $h_{c n w}$ は油の飽和度の大きさには関係なく, 水の飽和度によって変わり, $S_{w 0}=10 \%$ では約 $19 \mathrm{~cm}$, 


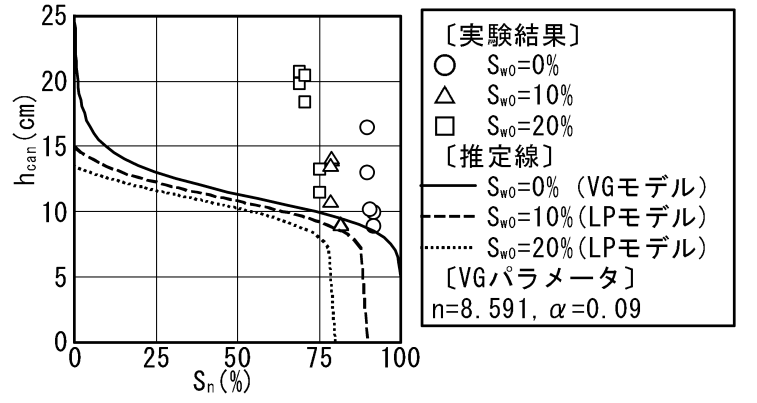

図-31 (a) 毛管上昇高〜油の飽和度の関係

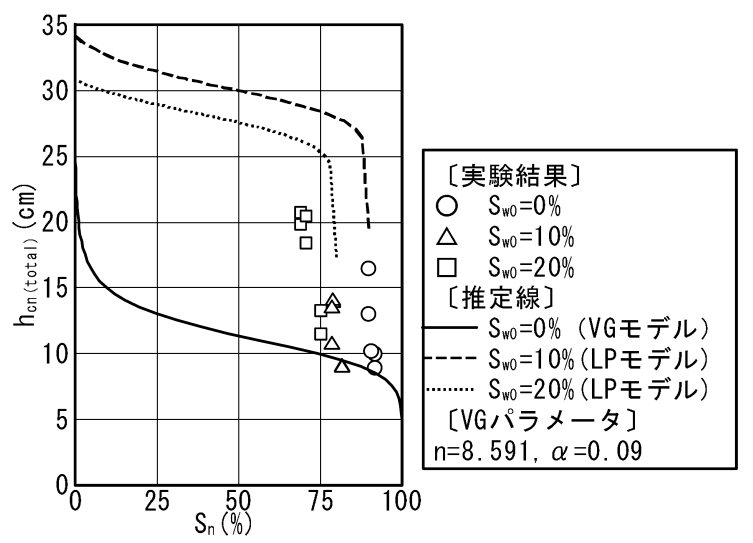

図-31 (b) 毛管上昇高と油の飽和度の関係

$S_{w 0}=20 \%$ では約 $17 \mathrm{~cm}$ である. 図-31 (b) では, LP モデルによる毛管上昇高の合算值は GAM モデルによ る毛管上昇高より大きく，両者は一致しないことがわ かる.

\section{GAM モデルによる鉛直一次元浸透実験}

オイルタンクより流出した油が地盤内の不飽和領域 を浸透降下する過程を対象に GAM モデルによる鉛直 一次元浸透実験を行った.

\section{（1）鉛直一次元浸透実験解析法}

図-32 に鉛直一次元浸透モデルを示す．鉛直一次元 浸透モデルにおいても問題を簡易にするために水平一 次元浸透モデルと同様の GAM 浸透モデルを適用する. すなわち, 土中の含水状態は浸潤面の両面で急変する ものとして，水頭分布は図-32 (c) に示すように直線部 分と仮定する. 以上の仮定を用いて, 流体の不飽和土 中への浸透現象を支配する物理定数である透油・透水 係数，毛管上昇高および有効間隙率を鉛直一次元浸透 実験により求める方法を示す.

鉛直一次元浸透では，GAM モデルより運動の式は 式 (39a) で表される，連続の式は式 (39b) で表される.

$$
V=k \frac{h_{0}+h_{c}+Z_{f}(t)}{Z_{f}(t)}, \quad V=\beta \frac{d Z_{f}(t)}{d t}
$$

ここで, $V:$ 流速 $(\mathrm{cm} / \mathrm{sec}), k$ : 透水係数 $(\mathrm{cm} / \mathrm{sec})$,
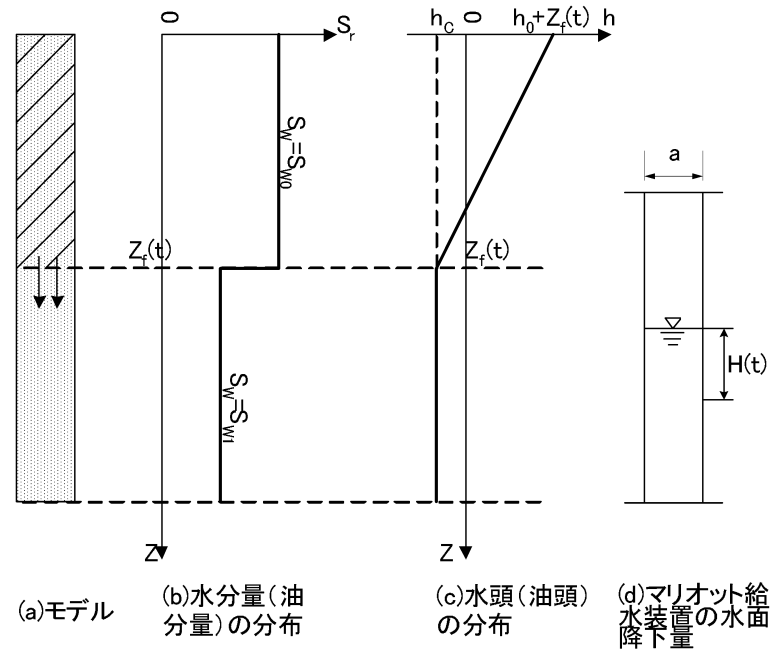

図-32 鉛直一次元浸透モデル

$h_{0}:$ 定水位 $(\mathrm{cm}), h_{c}$ : 毛管上昇高 $(\mathrm{cm})$,

$Z_{f}(t)$ : 浸潤面の位置 $(\mathrm{cm})$.

図-32 のように水位一定で浸透実験を行い，マリオッ 卜給水装置の水面降下量を $H(t)$ とすれば，式 (39b) は 次式のように表される.

$$
a \frac{d H(t)}{d t}=A \cdot \beta \cdot \frac{d Z_{f}(t)}{d t}
$$

ここで, $a$ : マリオット給水装置の断面積 $\left(\mathrm{cm}^{2}\right)$,

$A$ : 試料の断面積 $\left(\mathrm{cm}^{2}\right)$.

式 (39b) を式 (39a) に代入すると次式で表される.

$$
\beta \frac{d Z_{f}(t)}{d t}=k \frac{h_{0}+h_{c}+Z_{f}(t)}{Z_{f}(t)}
$$

式(41)を式(40)に代入すると次式で表される.

$$
a \frac{d H(t)}{d t}=A \cdot k \frac{h_{0}+h_{c}}{Z_{f}(t)}+A \cdot k
$$

また, 式 (40) を初期条件 $t=0$ で $H(t)=0, Z_{f}(t)=0$ で積分すれば，次式で表される.

$$
Z_{f}(t)=\frac{a \cdot H(t)}{A \cdot \beta}
$$

これを式 (42)に代入すると次式で表される.

$$
\frac{d H(t)}{d t}=\frac{A^{2}}{a^{2}} k \cdot \beta\left(h_{0}+h_{c}\right) \frac{1}{H(t)}+\frac{A}{a} k
$$

したがって, $d H(t) / d t \sim 1 / H(t)$ の関係は一次関数と して表される.

実験においては，定水頭 $h_{0}$ を 2 段階に変化させる. したがって，式 (44) は図-33 のグラフとなる.

グラフより $H_{0}=h_{01}$ 直線の傾き $m_{1}\left(\mathrm{~cm}^{2} / \mathrm{sec}\right), H_{0}=$ $h_{02}$ 直線の傾き $m_{2}\left(\mathrm{~cm}^{2} / \mathrm{sec}\right)$ および切片 $C(\mathrm{~cm} / \mathrm{sec})$ を 求める.

$$
\begin{gathered}
m_{1}=\frac{A^{2}}{a^{2}} k \cdot \beta\left(h_{01}+h_{c}\right) \\
m_{2}=\frac{A^{2}}{a^{2}} k \cdot \beta\left(h_{02}+h_{c}\right), \quad C=\frac{A}{a} k
\end{gathered}
$$




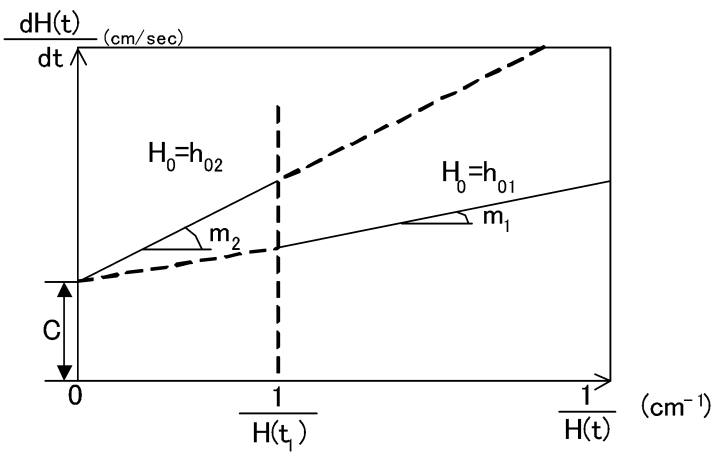

図-33 $d H(t) / d t \sim 1 / H(t)$ の関係 $\left(h_{01}<h_{02}\right)$

式 (45) を透油・透水係数, 有効間隙率, 毛管上昇高 について整理すると式 (46) で表される.

$$
\begin{gathered}
h_{c}=\frac{m_{1} h_{02}-m_{2} h_{01}}{m_{2}-m_{1}}, \quad k=\frac{a}{A} C \\
\beta=\frac{m_{1}}{C\left(h_{01}+h_{c}\right)} \frac{a}{A}
\end{gathered}
$$

また，有効間隙率 $\beta$ については，式 (41)を $\beta$ につい て整理すると式 (47) で表される. 有効間隙率 $\beta$ は $H(t)$ を縦軸にとり， $Z_{f}(t)$ を横軸にとったグラフの勾配を求 めると次式より求まる.

$$
\beta=\frac{a \cdot H(t)}{A \cdot Z_{f}(t)}
$$

\section{（2）鉛直一次元実験装置および実験方法}

実験装置は水平一次元と同様に内径 $4 \mathrm{~cm}$, 長さ $60 \mathrm{~cm}$ のアクリル製円筒を用い，定水位給水装置にはマリ オット給水装置を用いた。 供試体の乾燥密度は $\rho_{d}=$ $1.50 \mathrm{~g} / \mathrm{cm}^{3}$ である. 初期飽和度は 0〜 50\%の範囲で実験 を行った．実験は試料の下端を大気圧に開放し，給水 端に初期水頭 $h_{01}=20 \mathrm{~cm}$ を作用させ, 約 $30 \mathrm{~cm}$ 程度の 浸潤した時点で水頭を $h_{02}=40 \mathrm{~cm}$ に急変させた. 実 験において浸潤面の時間的変化 $\left(Z_{f}(t)-t\right)$, マリオッ 卜給水装置の水面（油面）の時間的変化 $(H(t)-t)$ を 計測した。なお，本実験では，浸潤終了後も給水を行 い, 定常となるまでの流出量を測定して, 透水係数を 求めた.

\section{（3）実験結果および考察}

\section{a） 透水・透油係数，有効間隙率と飽和度の関係}

図-34に透油・透水係数と初期飽和度の関係，図-35 (a), (b) に有効間隙率と間隙率の比と初期飽和度の関係 を示す. 透油・透水係数 $k_{1}$ および有効間隙率 $\beta_{1}$ は式 (46)より計算された值である.また，透油・透水係数 $k_{2}$ は式 (37a)により算定された值である. また, 有効間 隙率 $\beta_{S}$ のうち, 初期飽和度が $28.97 \%$ 以上の值は (37b) によって算定した. 他の $\beta_{S}$ は式 (47) より求めた.

図-34より，透水係数は水平一次元浸透実験の結果

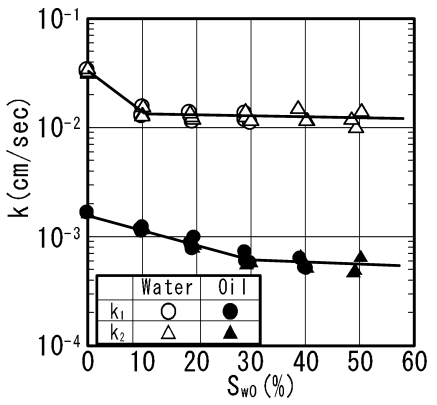

図-34 透油・透水係数と初期飽和度の関係

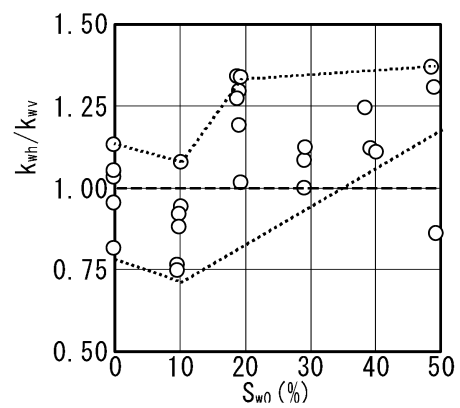

図-35 (a) 水平方向と鉛直方向の透水係 数の比と初期飽和度の関係

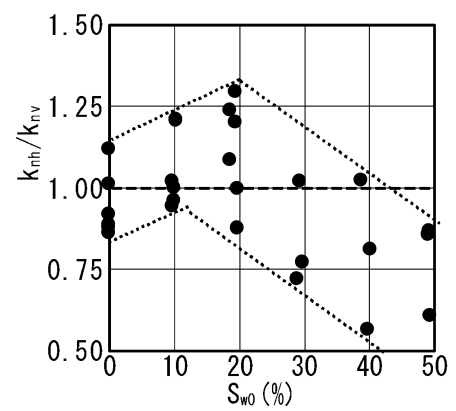

図-35 (b) 水平方向と鉛直方向の透油係 数の比と初期飽和度の関係

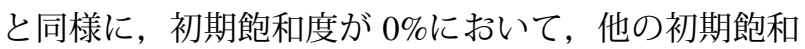
度の透水係数よりも少し大きいが全体的にほぼ一定と なった。透油係数は水平一次元浸透実験の結果と同様 に，初期飽和度が 30\%までは初期飽和度が増加ととも に減少し，初期飽和度が 30\%以上では，ほぼ一定の值 となった．初期飽和度が $30 \%$ 以上では，水の流出が見 られたことにより，透油係数は浸潤性の高い水の影響 を顕著に受け，水と油の混合流体の透水性を表してい ると考えられる。

図-35 に示す水平一次元浸透実験の結果と比較する と, 初期飽和度 $0 \sim 10 \%$ 範囲では, 両者はほぼ一致す る. しかし, 初期飽和度が 20〜 50\%の範囲では, 水平 一次元浸透実験の方が大きい.

図-35 (a) に水平方向と鉛直方向の透水係数を比較 した結果を示す。水を浸透させた場合, 初期飽和度が 0〜10\%までは, 透水係数比 $\left(k_{w h} / k_{w v}\right)$ は $0.76 \sim 1.12$ の 範囲である. 初期飽和度が $20 \%$ 以上では, 透水係数比 


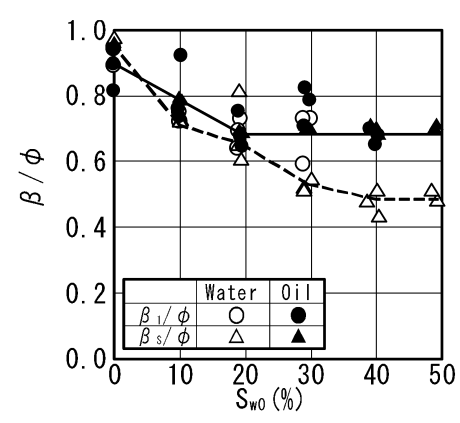

図-36 $\beta / \phi$ と初期飽和度の関係

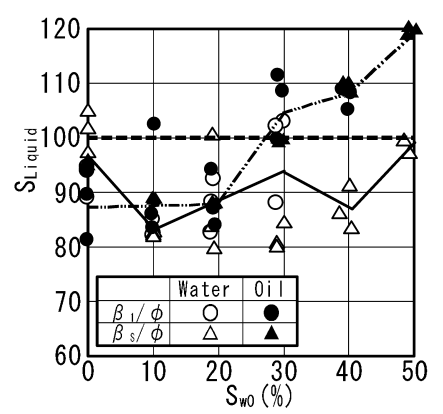

図-37 液体飽和度と初期飽和度の関係

$\left(k_{w h} / k_{w v}\right)$ は最大 1.3 程度となり, 水平一次元浸透実験 で得られる透水係数が大きいことがわかる.

図-35 (b) に水平方向と鉛直方向の透油係数を比較し た結果を示す．初期飽和度が 0〜20\%の範囲では，透 油係数比 $\left(k_{n h} / k_{n v}\right)$ は $0.8 \sim 1.3$ の範囲に分布し概ね 1 程 度である．初期飽和度が 30\%以上になると，透油係数 比 $\left(k_{n h} / k_{n v}\right)$ は漸減し, 初期飽和度が 50\%では, 透油係 数比 $\left(k_{n h} / k_{n v}\right)$ は 0.6 程度まで小さく, 鉛直一次元浸透 実験で得られる透油係数が大きいことがわかる.

図-36 に有効間隙率 $\beta$ と間隙率 $\phi$ の比 $(\beta / \phi)$ と初期 飽和度の関係を示す．浸透流体が水の場合には，初期 飽和度が $30 \%$ までは, 有効間隙率が徐々に小さくなり, 初期飽和度が $30 \%$ 以上では，ほぼ一定である．浸透流 体が油の場合には，初期飽和度が $20 \%$ までは有効間隙 率は徐々に小さくなり，初期飽和度が $20 \%$ 以上ではほ ぼ一定となる。初期飽和度が 30\%以上の場合には，油 の浸潤によって土中の水と油が置換して水が流出する 現象が見られた。

式 (38) で計算される液体飽和度と初期飽和度の関係 を図-37 に示す，油を浸透させた場合，水平浸透実験 と同様に初期飽和度が 30\%以上では，式 (37b) より流 入量と流出流量の差から, 有効間隙率 $\beta$ を求めている. 流出量には油だけでなく, 水も含まれているため, 有 効間隙率 $\beta$ が計算上大きくなり, 飽和度が $100 \%$ 以上 となった。

図-38 に，鉛直浸透実験と水平浸透実験の結果につ いて, 液体飽和度の平均值と初期飽和度の関係の比較 を示す．液体飽和度を平均化すると水平実験と鉛直実 験による液体飽和度には大きな差がないことがわかる.

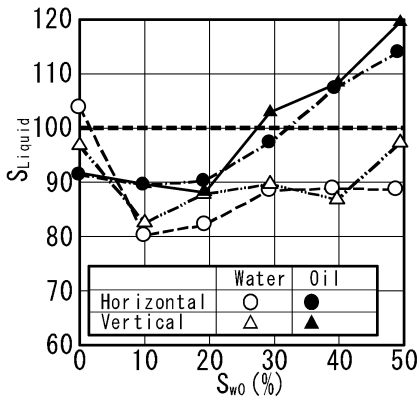

図-38 液体飽和度の平均值と初期飽 和度の関係

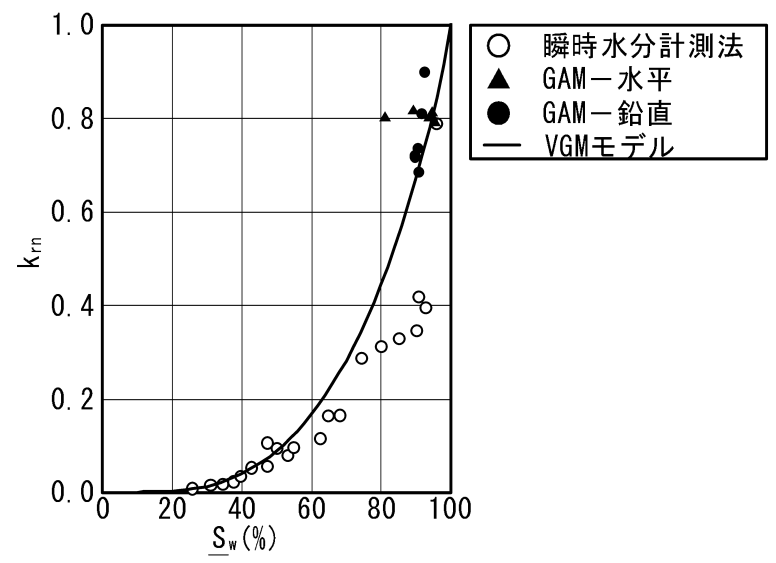

図-39 (a) 相対透過係数と有効飽和度の関係 (油一空気二相系)

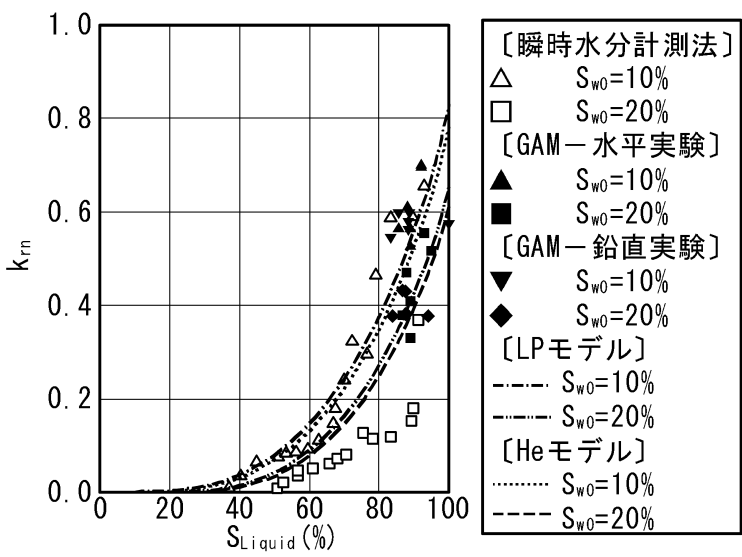

図-39 (b) 相対透過係数と液体飽和度の関係 (三相系)

図-39 (a) は油一空気の二相系における相対透油係数 と水の有効飽和度の関係である，GAM モデルにより 求めた相対透油係数は, VGM モデルによる推定線上に プロットされていることがわかる.

図-39 (b) は三相系での相対透油係数と液体飽和度の 関係である. GAM モデルにより求めた相対透油係数 は瞬時水分計測法と同程度の精度であり，LP モデルお よび He モデルの推定線に沿っていることがわかる.

したがって, GAM モデルにより二相, 三相系での油 の透油係数を求めることが可能であると判断される. 


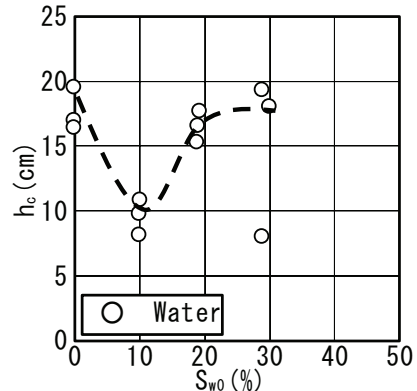

図-40 (a) 毛管上昇高と初期飽和度の関係 (流体：水)

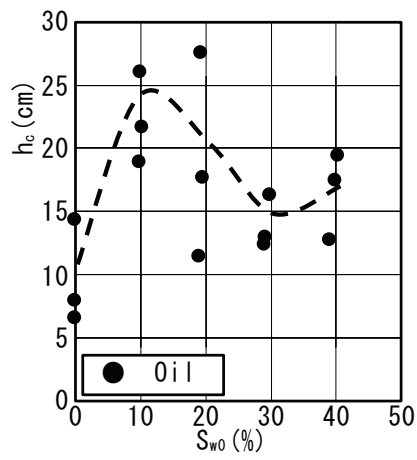

図-40 (b) 毛管上昇高と初期飽和度の関係 （流体：油）

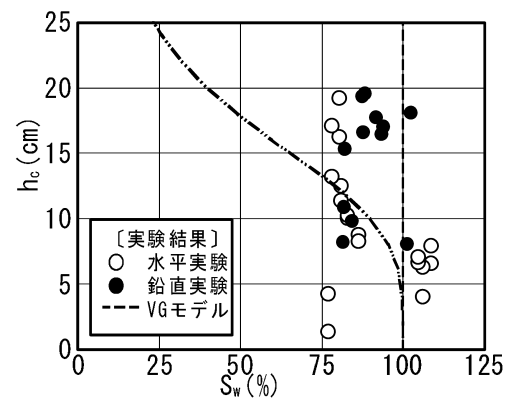

図-41 毛管上昇高と水の飽和度の関係 (水一空気二相系)

\section{b）毛管上昇高と初期飽和度の関係}

図-40 (a), (b) に毛管上昇高 $h_{c}$ と初期飽和度 $S_{w 0}$ の関 係を示す．図-40 (a)より，水の場合には，毛管上昇高 は初期飽和度が 0〜30\%の範囲で $8.1 \mathrm{~cm} \sim 19.3 \mathrm{~cm}$ であ る. 初期飽和度が $10 \%$ で低く, 初期飽和度 $0 \%$, 初期 飽和度 20〜30\%で大きい。

図-40 (b) より，油の場合には，毛管上昇高は初期飽 和度が 0〜30\%の範囲では $6.5 \mathrm{~cm} \sim 27.5 \mathrm{~cm}$ の範囲であ る. 初期飽和度が 10\%で大きく，水の毛管上昇高の変 動と相反する傾向となった.

図-41に水一空気の二相系における水の飽和度と毛 管上昇高の関係を示す。水平実験および鉛直実験とも データにばらつきがあり, 両者に明確な差はない。 ま た, VG モデルによる推定線は実験結果の平均付近を 通ることがわかる.

図-42に三相系における毛管上昇高と油の飽和度の 関係を示すＬPモデルによる推定線は空気一油間の毛

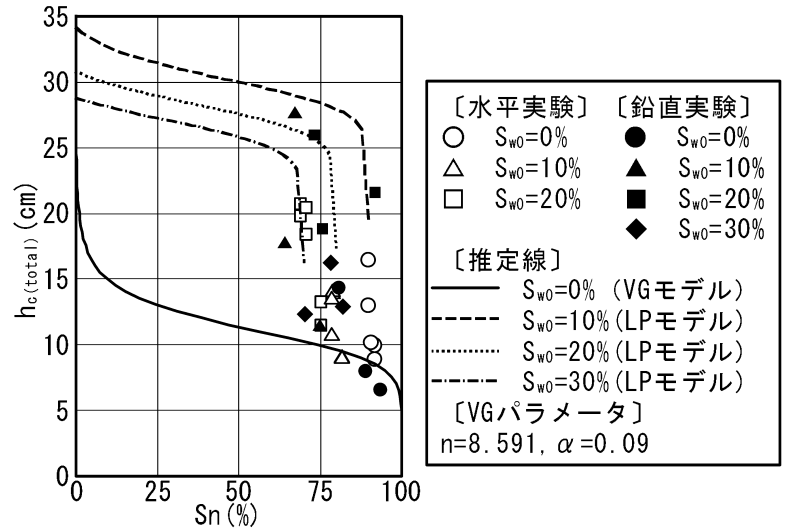

図-42 毛管上昇高と油の飽和度の関係

管上昇高 $h_{c a n}$ と油一水間の毛管上昇高 $h_{c n w}$ を合算值と した. GAM モデルより推定される毛管上昇高は鉛直 一次元浸透実験と水平一次元浸透実験ともばらつきが あり, 余り大きな差はない. また, LP モデルの毛管上 昇高の合算值と GAM モデルによる毛管上昇高は一致 しない。

水平一次元実験と鉛直一次実験によって，初期状態 が乾燥状態と湿潤状態での水と油による浸透実験を実 施し，GAM モデルに基づき有効間隙率，透油係数，透 水係数，毛管上昇高を求めた. GAM モデルの仮定が 成り立つのは, 水が移動しない範囲である. 今回の実 験では, 初期飽和度が 30\%以上では水の移動を確認し たことから, GAM モデルが成り立つのは, 初期飽和度 が 30\%以下である.

GAM モデルによって得られる相対透油係数と飽和 度の関係は, 油の浸透によって, 水が移動しない範囲 内では十分な精度をもって求めることができる. 今回 の実験では, 水の飽和度が 0〜 20\%の範囲, 油の飽和度 が 80〜 100\%の範囲で適用可能である. 一方, GAM モ デルより求まる毛管上昇高は, ばらつきが大きく, 解 析に適用することは難しいと考えられる.

\section{9. 油の浸透特性の適用法}

二相系および三相系の浸透流解析では, 毛管上昇高一 飽和度一相対透水系数を求めることが必要である. 本 研究で実施した実験結果と実際の挙動の定量的な評価 における実験手法の適用法について以下に述べる.

\section{（1） $\gamma$ 線による瞬時水分計測法による鉛直一次元浸透 実験}

$\gamma$ 線による瞬時水分計測法による空気一油一水の三 相系において，最も効果的な活用は，油の浸透や移動 が卓越し，水の移動がほとんどない状態である。この ような状態においては, 空気と油の二相の浸透流に着 目し，予測解析すればよい．今回の実験で得られた毛 
管上昇高一飽和度一相対透過係数の関係を解析に適用 することができる.

油および地下水の両者が移動するような状態におい ては, $\gamma$ 線による瞬時水分計測法による毛管上昇高一 飽和度一相対透過係数の関係を測定することは難しい. そのような場合には, 次のように二相系の実験から毛 管上昇高一飽和度一相対透過係数を求める必要がある.

毛管上昇高と飽和度の関係は, VG モデルによる土粒 子の構造骨格から決定される $n$, フィッティングパラ メータ $\alpha$ により表現される. $\gamma$ 線による瞬時水分計お よび圧力変換機を用いて, 空気一水の二相系での毛管 上昇高一飽和度一相対透過係数の関係を求めることが できる.これによって, VG モデルパラメータである $n$ および $\alpha_{a w}$ を決定することができる. また, 空気一油 の二相系での実験より，毛管上昇高一飽和度一相対透 過係数の関係から, VG パラメータである $\alpha_{a n}\left(=\alpha_{a w}\right.$ $\left.\times \beta_{a n}\right)$ を求めることができる. $\gamma$ 線による瞬時水分計 測法では, 油と水の両者が移動する場合には適用でき ないため, 水一油の二相系での VG パラメータである $\alpha_{n w}\left(=\alpha_{a w} \times \beta_{n w}\right)$ は, $\beta_{a w}=1.0$ および $\beta_{n w}$ が既知であ るため, 式 (15) より $\beta_{n w}$ を求めて, 決定することが可 能である.

\section{（2）油の物性および変水位透油試験}

油が温度によって, 粘性係数および密度が変化する 特性を用いて，図-6に示すように透油係数 $k$ と $\rho g / \mu$ の線形関係から対象土の物理的透過係数 $K_{0}$ を求める ことができる. 物理的透価係数を把握すれば, 流体の 粘性係数 $\mu$ と密度 $\rho$ だけで, 流体の浸透係数（透水係 数, 透油係数）を計算でき，実験の省力化を図ること ができる.

また, 試験供試体に含まれる水分量を変化させて, 透 油係数を求めることによって, 油の移動が制限され, 油 が流れなくなる含水量を概ね予測できる。

\section{（3）GAM モデルによる浸透実験}

GAM モデルによる浸透実験は, 油の浸透によって 間隙水が移動しない範囲では, 空気一油一水の三相系 での透油係数一飽和度の関係を求めることが可能であ る. また, 油の地下タンク内の圧力および地盤の水飽 和度を初期条件として得ることができれば, 油の浸透 量および浸透速度, 更に, 毛管上昇高, 有効間隙率, 透 油係数を求めることができる有効な方法であると考え られる。

\section{（4）今回の浸透実験が適用できる地盤}

今回の実験では，対象土として透水性が比較的良い 豊浦標準砂を用いて, 油の浸透特性に関する実験を行っ
た.これは, 油による土壌污染は透水性の高い地盤で 油が拡散することを考慮したものである．この結果は， 関東平野での江戸川砂, 王子砂, 成田砂等の豊浦標準 砂に類似した砂質土にも適用できる. なお，粘性土の ように透水性が低い地盤は難透水境界となることから， 粘性土を対象とした油の浸透実験は実務上の必要性は ほとんどないと考える。

\section{0. 結論}

本研究では, $\gamma$ 線を用いた瞬時水分計測法により, 空 気一油一水の三相系における毛管上昇高一飽和度一相 対透過係数の関係を求め, 油の浸透特性を調査するた めの比較的簡便な方法として, 変水位透水試験および GAM モデルによる浸透実験を実施して, それらの試 験法の適用性を検証した. 以下に, 本研究で得られた 結論を以下に列挙する。

（1）変水位透水試験より，粘性係数と飽和透油係数の 関係を求めた. その結果, 温度変化に伴う油の密度 と粘性係数の比 $\left(\rho_{\mathrm{oil}} g / \mu_{\mathrm{oil}}\right)$ と飽和透油係数 $k_{\mathrm{oil}}$ には 比例関係が認められた. また, この関係より, Taylor の関係に基づき, 物理的透過係数 $K_{0}$ を求めることが 可能であることが確認された. また, 試験供試体に 含まれる水分量を変化させて, 透油係数を求めるこ とによって, 油の移動が制限され, 油が流れなくな る含水量を概ね予測できる.

（2）GAM モデルによる水平・鉛直一次元浸透実験を 行い, 毛管上昇高, 有効間隙率, 透水・透油係数を 求めた. 両実験とも，初期飽和度 0 ～50\%の 5 段階 に対して実施した. 油を浸透させた実験では, 初期 飽和度が 30\%以上では, 透油による供試体内の水の 流出が確認された. 水の移動流出がない初期飽和度 20\%までの実験結果では, GAM モデルによる相対透 油係数と飽和度の関係は, 瞬時水分測定法による実 験結果とほぼ一致したことがわかった。 また, 初期 飽和度が $20 \%$ までは, 透油係数は鉛直方向と水平方 向での相違はほとんどなく, 初期飽和度が $30 \%$ 以上 では，鉛直方向の透油係数が水平方向よりも大きい ことが確認された。 透水係数は初期飽和度が $30 \%$ 以 上では，水平方向の透水係数が鉛直方向よりも大き いことが確認された.

（3）GAM モデルより推定される毛管上昇高は鉛直・水 平一次元浸透実験ともにばらつきがあり, 解析に適 用するためには精度上の問題がある.

地下タンクから油が漏洩した時, 油の浸透状況は地 盤に含まれる水の飽和度の影響を受ける. この研究で 用いた $\gamma$ 線による瞬時水分計測法, GAM モデルによ 
る水平・鉛直一次元浸透実験は，地盤に含まれる水の 飽和度が低く, 油の浸透が卓越する条件で適用される 実験である。

GAM モデルは相対透過係数と飽和度の関係を求め る上では，比較的簡易な試験法である．しかし，GAM モデルで得られる毛管上昇高には精度上の問題がある ことがわかった．今後の課題の 1 つとして，GAM モ デルで計算される毛管上昇高の補正を行い精度を確保 することが必要である.

また，今回の実験では，地下水面付近のように水の 飽和度が高く, 油と水の両方が移動するような場合に は適用できない. 特に, 地下水面付近では, 油は地下 水の流れに沿って移動することがわかっている.

したがって, 地下水面近くでの油の多孔質体中の挙 動を説明することは，ここで用いた方法では困難であ る.このような水で飽和に近い領域に対しては， $\gamma$ 線 密度計で土粒子の間隙内の空気が水や油でどの程度置 換されているかを計測し, 置換された液体に対して, 水と油がどの程度の割合であるかを土塊の誘電率の変 化を計測することによって求めると考えられる ${ }^{53)}$. ま た，土塊の中に水がどの程度含まれているかを計測す るには中性子を用いた土壌水分計を用いることによっ て計測が可能である．これらを総合すると，不飽和土 中を移動する油のすべての領域での挙動を定量的に計 測するには RI（ $\gamma$ 線, 中性子）と誘電率計と水, 油の テンションメータ（負の間隙水圧計）を用いた計測手 法が有効であると考えられる.

謝辞：本研究を推敲するにあたり，大変な実験を助け てくれた三宅研次君（岡山大学卒業生, 現倉敷市建設 部）に感謝の意を込めてここに記して謝辞とする.

\section{参考文献}

1) 環境省: 平成 16 年度土㙵污染対策法の施行状況及び土 壌污染調查・対策事例等に関する調查結果，平成 18 年 11 月，71p. (環境省ホームページ)

2) 平田健正 : 土袞・地下水污染問題と対策の動向, 地下水 学会誌, Vol.44, No.4, pp.317-323, 2002.

3) 平田健正：土壌污染対策法の施行と修復技術開発, 日 本地下水理化学研究所論文収録集, 第 47 巻, 第 10 号, pp.70-77, 2006.

4）日本地下水学会編：地下水・土境污染の基礎から応用, 理工図書, pp.1-26, 2006.

5）西垣誠：土壌・地下水污染の歴史と現状，基礎工，No.6, pp.2-7, 2005.

6) アジア砒素ネットワーク他: 第 11 回アジア地下水七素 污染フォーラム予稿集, pp.1-6, 2006.

7）日本地下水学会編：地下水・土壌污染の基礎から応用, 理工図書, pp.223-251, 2006.

8) 深見正仁: 滋賀県に打ける地下水污染の現状と対策, 滋 賀県琵琶湖研究所所報, No.8, pp.58-64, 1990.

9）地盤工学会: 土壌・地下水污染の調查・予測・対策, p.271, 2003.

10) Leverett, M. C.: Capillary Behavior in porous solids, Trans.
Am. Inst. Min. and Metall. Pet. Eng., Vol.142, pp.152-169, 1941.

11) Brooks, R. H. and Corey, A. T.: Hydraulic properties of porous media, Hydrology Paper. 3, Colorado State University, Fort Collins, 1964.

12) Van Genuchten, M. Th.: A closed-form equation for predicting the hydraulic conductivity of unsaturated soils, Soil Sci. Soc. Am. J., Vol.44, pp.892-898, 1980.

13) Parker, J. C. and Lenhard, R. J.: A model for hysteretic constitutive relations governing multiphase flow: 1 . saturationpressure relations, Water Resour. Res., Vol.23, No.12, pp. 2187-2196, 1987.

14) Parker, J. C., Lenhard, R. J. and Kuppusamy, T.: A parametric model for constitutive properties governing multiphase flow in porous media, Water Resour. Res., Vol.23, No.4, pp.618-624, 1987.

15) Lenhard, R. J. and Parker, J. C.: Experimental validation of the theory of extending two-phase saturation-pressure relations to three-fluid phase systems for monotonic drainage paths, Water Resour. Res., Vol.24, No.3, pp.373-380, 1988.

16) Lenhard, R. J., Dane, J. H., Parker, J. C. and Kaluarachchi, J. J.: Measurement and Simulation of one-dimensional transient three-phase flow for monotonic liquid drainage, Water Resour. Res., Vol.24, pp.853-863, 1988.

17) Lenhard, R. J., Parker, J. C. and Kaluarachchi, J. J.: A model for hysteretic constitutive relations governing multiphase flow, 3. Model Refinements and simulations, Water Resour. Res., Vol.25, pp.1727-1736, 1989.

18) Burdine, N. T.: Relative permeability calculations from poresize distribution data, Pet. Trans., Am. Inst. Min. Metall. Eng., Vol.198, pp.71-77, 1953.

19) Mualem, Y.: A new model for predicting the hydraulic conductivity of unsaturated porous media, Water Resour. Res., Vol.12, pp.513-512, 1976.

20) Stone, H. L.: Probability model for estimating three-phase relative permeability, Trans. SPE of AIME., Vol.249, No.4, pp.214-218, 1970.

21) Stone, H. L.: Estimation of three-phase relative permeability and residual oil data, Journal Can. Petro. Technol., Vol. 12, No.4, pp.53-61, 1973.

22) Van Geel, P. J. and Sykes, J. F.: Laboratory and model simulations of a LNAPL spill in a variably-saturated sand. 1. Laboratory experiment and image analysis technique, $J$. Contam. Hydrol., Vol17, pp.1-25, 1994.

23) Van Geel, P. J. and Sykes, J. F.: Laboratory and model simulations of a LNAPL spill in a variably-saturated sand. 2 . Comparison of laboratory and model results, J. Contam. Hydrol., Vol17, pp.26-53, 1994.

24) Van Geel, P. J. and Roy, S. D.: A proposed model to include residual NAPL saturation in a hysteretic capillary pressuresaturation relationship, J. Contam. Hydrol., Vol.58, pp.79110, 2002.

25) Wipfler, E. I. and Van Der Zee, S.E.A.T.M.: A set of constitutive relationships accounting for residual NAPL in the unsaturated zone, J. Contam. Hydrol., Vol.50, pp.53-77, 2001.

26) Lenhard, R. J., Oostorm, M. and Dane, J. H.: A constitutive model for air-NAPL-water flow in the vadose zone accounting for residual NAPL in strongly water-wet porous media, J. Contam. Hydrol., Vol.71, pp.261-282, 2004.

27) Oostorm, M., White, M. D., Lenhard, R. J., Van Geel, P. J., Wietsma, T. W.: A comparison of models describing residual NAPL formation in the vadose zone, VADOSE ZONE J., Vol.4, pp.163-174, 2005.

28）藤縄克之, 高橋真: 通気帯における石油系炭化水素の 毛管移動現象に関する基礎的研究, 土木学会論文集, No.762/VII-31, pp.69-81, 2004. 
29）棚橋秀行，佐藤健：鉛直飽和カラムにおける油の浸入・ 残留飽和度と水分保持特性曲線の関係について, 第三回 環境地盤工学シンポジウム, pp.197-200, 1999.

30) 登坂博行, 伊藤一誠, 蛯原雅之, 稲葉薰, 伊藤彰, 小島桂 二：多成分多相型移流拡散モデルによる包括的な地下水 污染解析, 地下水学会誌, 第 38 巻, 第 3 号, pp.167-180, 1996.

31) 多田和広, 森康二, 田仲元, 登坂博行 : 非水相液体（油） の地下水三相流動パラメータに関する検討, 地下水学会 春季講演会, pp.20-5, 2003.

32) Hinkelmann, R.: Efficient Numerical Methods and Information-Processing Techniques for Modeling Hydro-and Environmental Systems, Springer, 299p., 2005.

33) Helmig, R. 著, 平田健正, 樫山和男監訳, 小林健一郎訳 : 地下水環境での多相流と輸送現象, シュプリンガー・フェ アラーク東京, p.72, 2004 .

34) 藤縄克之: 地盤環境污染の現状とその対策 (6) 地盤環境污 染の解析手法, 土と基礎, Vol.42, No.8, pp.71-78, 1994.

35) 藤縄克之, 日比義彦: 移流分散解析入門 (4) 地盤内の物 質移動方程式一多相流問題一, 土と基礎, Vol.50, No.11, pp.66-70, 2002.

36) 藤縄克之, 日比義彦: 移流分散解析入門 (9) 地盤内の多 相流解析，土と基礎，Vol.51，No.4, pp.51-56, 2003.

37) 藤縄克之, 日比義彦, 藤原幸彦: 多孔体中における水一 疎水性液体一気体の等温多相流れに関する研究の進歩, 農業土木学会論文集，No.214，pp.149-158， 2001.

38) 文献 33)の pp.35-57, 2004.

39) Lenhard, R. J. and Parker, J. C.: A model for hysteretic constitutive relations governing multiphase flow: 2 . Permiability-saturation relations, Water Resour. Res., Vol.23, No.12, pp.2197-2206, 1987.

40) Lenhard, R. J. and Parker, J. C.: Measurement and prediction of saturation-pressure relationship in three phase porous media systems, J. Contam. Hydrol., Vol.1, No.4, pp.407-424, 1987.

41) 文献 33) の p.55, 2004.

42) Taylor, D. W.: Fundamentals of Soil Mechanics, John Wiley \& Sons, Inc., pp.104-122, 1961.

43）地盤工学会編集委員会: 不飽和地盤の挙動と評価, pp.56-
74, 2004.

44) Van Bavel, C. H. M., Stirk, G. B. and Brust, K. J.: Hydraulic Properties of a Clay Loam Soil and the Field Measurement of Water Uptaken by Roots, I. Interpretation of Water Content and Pressure Profiles, Soil Sci. Soc. Amer. Proc., Vol.32, pp.310-317, 1968.

45) Davidson, J. M., et al.: Field Measurement and Use of SoilWater Properties, Water Resour. Res., Vol.5, pp.1312-1321, 1969.

46) Hillel, D., Krentons, V. D. and Stylianou, Y.: Procedure and Test of an Internal Drainage Method for Measuring Soil Hydraulic Characteristics in Situ, Soil Sci., Vol.114, No.5, pp.395-400, 1972.

47）河野伊一郎, 西垣誠, 賴木清隆: ガンマ線による土中水分 変化の測定, 第 14 回土質工学研究発表会, pp.1137-1140, 1979.

48）河野伊一郎, 西垣誠 : 不飽和砂質土の浸透特性に関する 実験的研究, 土木学会論文報告集, 第 307 号, pp.59-69, 1981.

49) Vachaud, G. and Thony, J. L.: Hysteresis during Infiltration and Redistribution in a Soil Column at Different Initial Water Contents, Water Resour. Res., Vol.7, pp.111-127, 1971.

50) Hoa, N. T., Gaudou, R. and hirriot, C. T: Influence of the Hysteresis Effect on Transient Flows in Saturated-Unsaturated Porous Media, Water Resour. Res., Vol.13, No.6, pp. 992-996, 1977.

51) Green, W. H. and Ampt, C. A.: Studies on soil physics, 1, Flow of air and water through soils, J. Agric. Sci., Vol.4, pp.1-24, 1911.

52) McBride, J. F., Simsons, C. S. and Cary, J. W.: Interfacial spreading effects on one-dimensional organic liquid imbibition in water-wetted porous media, J. Contam. Hydrol., Vol.11, pp.1-25, 1992.

53）西垣誠, 小松満, 金萬鎰：FDR 法による土壌・地下水污 染のモニタリング手法に関する基礎的研究, 地下水学会 誌，第 46 巻，第 2 号, pp.145-157, 2004.

(2007. 1. 12 受付)

Contamination problems in soil and groundwater are major rising problems in many places. In this paper, oil contamination is the focus and how to quantitatively estimate the hydraulic characteristics of water, gas and oil (3-phase liquid) in porous material is discussed. Laboratory experiments were carried out using a simplified method based on the Green-Ampt model and a complex method based on the instantaneous profile method by using gamma rays. A comparison of the results determined from both methods was discussed. The limitation of the Green-Ampt method in nearly saturated conditions is also mentioned. 